\title{
Liturgy as History: The Origins of the Exeter Martyrology
}

Sarah Hamilton, University of Exeter

\section{$\underline{\text { Abstract }}$}

Through an Anglo-Norman case study, this article highlights the value of normative liturgical material for scholars interested in the role which saints' cults played in the history and identity of religious communities. The records of Anglo-Saxon cults are largely the work of Anglo-Norman monks. Historians exploring why this was the case have therefore concentrated upon hagiographical texts about individual Anglo-Saxon saints composed in and for monastic communities in the post-Conquest period. This article shifts the focus away from the monastic to those secular clerical communities which did not commission specific accounts, and away from individual cults, to uncover the potential of historical martyrologies for showing how such secular communities remembered and understood their own past through the cult of saints. Exeter Cathedral Library, Ms 3518, is a copy of the martyrology by the ninth-century Frankish monk, Usuard of Saint-Germain-des-Prés, written in and for Exeter cathedral's canons in the mid-twelfth century. Through investigation of the context in which it was produced and how its contents were adapted to this locality, this article uncovers the various different layers of the past behind its compilation. It further suggests that this manuscript is based on a pre-Conquest model, pointing to the textual debt Anglo-Norman churchmen owed to their Anglo-Saxon predecessors. 
Writing in the early twelfth century about the Devon monastery of Tavistock, William of Malmesbury observed that its local cult, like that of others elsewhere in England, relied on oral traditions rather than writing, and explained why this was the case:

"Rumon is celebrated there as holy and buried as a bishop. He is adorned with a beautiful shrine but what is said about him is not buttressed by the solid authority of writing. You will find this situation in many other places in England as well: that no doubt as a result of enemy violence, all records of the past have been destroyed, leaving only the bare names of the saints and of any miracles they still perform." The destruction of earlier records by "enemy violence" is now recognised as a general trope of hagiographical writings from across north-western Europe in this period, be the enemy the north men, Danes, or Hungarians; it is unlikely that any such writings as alluded to by William ever existed. ${ }^{2}$ Although modern scholars, therefore, reject William's explanation of the reasons for the absence of hagiography, they follow him in accepting that Anglo-Norman churchmen did not inherit a substantial written legacy from their Anglo-Saxon predecessors in support of the cult of saints, and in seeking to explain why Anglo-Norman churchmen were so interested in recording the histories of local cults. ${ }^{3}$ But, as we shall see, modern historiography has focussed mainly on monastic communities that commissioned hagiographical texts for particular cults, and by doing so largely ignores the cultic histories of secular communities in this period. Moreover, this research concentrates on a relatively narrow range of material, that is the narrative and poetic lives, accounts of translations, and those of miracles, largely treating other liturgical evidence, much of it helpfully edited, of calendars, litanies, chants, relic lists, and martyrologies, as ancillaries to them. ${ }^{4}$ In focusing on only one strand within the surviving record, historians of Anglo-Norman cults have lagged behind scholars working on the continental materials from the same period. In particular the musicologists Susan Boynton and Margot Fassler have demonstrated the value of exploring a 
range of liturgical materials for evidence of developments in the institutional identities of two important ecclesiastical communities in this period, the powerful central Italian monastery of Farfa, and the influential French cathedral of Chartres. ${ }^{5}$ More recently, Fassler helped edit an important collection of essays on the ways in which cantors contributed to the making of history in medieval monastic, and to a lesser extent cathedral, communities through liturgy and historical writing. ${ }^{6}$ Whilst highlighting the centrality of, and richness of, the liturgical evidence, these works pay more attention to the chants, hymns, and lections associated with particular cults than the more normative texts of the type considered here whose contents as well as structure were much more rigid. ${ }^{7}$ Normative is used here to distinguish those liturgical texts whose form and content were broadly similar across different institutions, such as calendars, litanies, relic lists, martyrologies and sacramentaries, from the more narratival texts used in the support of particular cults, such as saints' lives, translation accounts, miracle collections, and hymns.

Building on their approach, this article sets out to provide a corrective to the current work of Anglo-Norman historians through a case study of one mid-twelfth-century manuscript, a copy of the ninth-century historical martyrology composed by Usuard, now Exeter Cathedral Library Ms 3518 (hereinafter Exeter 3518), which was made for Exeter cathedral's secular community of canons. By arguing that this manuscript is based on an earlier, eleventh-century English exemplar, it suggests firstly the value of investigating such normative liturgical material for what it can tell us about how one Anglo-Norman secular community, at least, understood their history, and secondly that this particular community inherited a very helpful textual, as well as oral, legacy from the pre-Conquest period. Uncovering the different layers of additions to this ninth-century text reveals how this manuscript, which was, as we shall see, in daily use throughout the later twelfth and thirteenth centuries, embodied the Exeter community's understanding of their own past, and 
reveals how they situated their own history within that of the universal Church. In offering a perspective from a secular, albeit regular, community on current interpretations of the memory of saints across the Conquest it helps switch modern scholars' attention away from specific cults to focus instead on the ways in which communities sought to place their local church within the wider communion of saints.

\section{LACUNAE IN MODERN SCHOLARSHIP}

Secular communities like that of Exeter cathedral are generally disregarded in modern accounts of the development and circulation of hagiographical writings in this period. This is because the hagiographical narratives written in England in the period between 950 and 1130 were produced by and for monastic communities. It is now recognised that the AngloNorman resurgence was preceded by an earlier revival in hagiographical writing within England which began c. 950 and lasted until the second quarter of the eleventh century. ${ }^{8}$ Starting in the great centres of the tenth-century reform movement, this initial revival later spread to smaller houses as Anglo-Saxon churchmen began to record previously undocumented local cults in lives, translation and miracle accounts. ${ }^{9}$ The same monastic monopoly on authorship and audience is also true of the compositions in the third wave of hagiographical writing, those commissioned by members of the new Anglo-Norman hierarchy in the first sixty or so years after the Conquest. However, monasteries served only a minority of churches at this time. As the Old English tract, Secgan be Pam Godes sanctum Pe on Engla lande aerost reston (The Resting Places of the English Saints) (c. 1031)), listing the location of some eighty-nine named cults in late Anglo-Saxon England, demonstrates, most

cults in this period were associated instead with secular communities. ${ }^{10}$ But, in James Campbell's words, seculars "did not write books"; as a consequence, almost nothing is known about such cults beyond their names and whereabouts before they were taken over, 
and subsequently documented, by reforming monks in the later eleventh and twelfth centuries. ${ }^{11}$

Modern research instead focuses almost exclusively on the hagiographical texts written by and for these reformed communities. Earlier scholars, beginning with David Knowles and Richard Southern, following Eadmer's comments that Lanfranc was initially opposed to English cults, argued that churchmen set out to document established local cults in the face of scepticism from the new Norman hierarchy in the post-Conquest period. ${ }^{12}$ Susan Ridyard rejected this view, showing instead that the explosion in the production of Anglo-Latin hagiography in the later eleventh and early twelfth centuries owed more to the efforts of individual Norman churchmen who wanted to establish their authority over particular local churches. ${ }^{13}$ Rosalind Love went further, suggesting that it also represents Anglo-Norman attempts to assimilate culturally into an unfamiliar, more vernacular world, through the control and documentation of existing cults. ${ }^{14}$ Subsequent scholars have shied away from generalisations, and in doing so highlighted that the main reason why individual communities commissioned narrative hagiographies for particular cults was to support claims to authority at moments of institutional crisis or change; at the same time, they have shown that the decision to document a particular Anglo-Saxon cult often led to the deliberate neglect of other existing ones previously observed by that community. ${ }^{15}$

At the same time, those working on Anglo-Saxon hagiography across the later tenth and earlier eleventh centuries have drawn attention to the significance of a considerable body of liturgical evidence for the knowledge of English saints in this period. ${ }^{16}$ In particular they have focussed scholars' attention, through easily available modern editions, on calendars and litanies, as well as relic lists; martyrologies, by contrast, have been rather more neglected. ${ }^{17}$ Although those working on the Anglo-Norman period also recognise the value of such liturgical material, they generally only look to it to supplement the narrative texts. Its 
significance was recognised in 1999, for example, by Jay Rubenstein who pointed out how the calendrical evidence from Christ Church, Canterbury provided support for Eadmer's avowal that Lanfranc was not interested in English saints, and suggested that the excision of local cults from Canterbury's calendar resulted not so much from the new archbishop's scepticism but rather from his desire to promote more universal saints. ${ }^{18} \mathrm{He}$ devoted the bulk of his attentions, though, to Eadmer's hagiographical writings. More recently Benjamin Pohl has investigated the obit notices in the martyrological and necrological evidence from the Norman house of Bec to suggest they served as sources for Robert of Torigni's twelfthcentury redaction of the Gesta Normannorum Ducum..$^{19}$

In 1983 John M. McCulloh observed that historical martyrologies have largely been left out of the historiographical turn to hagiography. ${ }^{20}$ This still remains largely true over thirty years later. Despite their potential, they have not yet been much studied by students of Anglo-Norman cults. Yet they provide valuable evidence of the state of knowledge about saints' cults within a community, because martyrologies were practical books. From the Aachen reforms of the early ninth century onwards, it was the custom to read from martyrologies daily in chapter in both monastic and canonical communities as guides to the cults to be remembered the coming day. ${ }^{21}$

More recently, researchers working on the eighth and ninth centuries have begun to recognise the value of historical martyrologies as records of churchmen's knowledge of saints' cults, understanding of Christian history and the role of their own locality within it. ${ }^{22}$ The compilers of influential texts, including those by Bede, the Anonymous of Lyon and Ado of Vienne, created a historical geography of the Christian world for their readers. Entries arranged according to the Roman calendar set out not just the names of the saints to be commemorated on that day but the location of their cults and sometimes, in the case of martyrs, named the emperor under whom they were persecuted and the torments they 
suffered. To date scholars of the later Anglo-Saxon reforms have focussed mainly on the idiosyncratic vernacular text now known as the Old English Martyrology rather than the Latin products of the Carolingian reforms. ${ }^{23}$ They have, however, noted the introduction of one product of the ninth-century Frankish reforms, the Latin historical martyrological text compiled by Usuard of Saint-Germain-des Près (d. 877). Usuard's work became, at least in northern continental Europe, one of the most popular martyrologies amongst eleventh- and twelfth-century monasteries, and surviving manuscripts, as we shall see, testify to its popularity in England from the late eleventh century onwards. ${ }^{24}$ But only one manuscript of this text now survives from Anglo-Saxon England: Cambridge, Corpus Christi College, Ms 57 (hereinafter CCCC 57). Mechthild Gretsch has linked the introduction of its model to England to the monastic reformer and Archbishop of Canterbury, Dunstan (d. 988). ${ }^{25}$ CCCC 57 was probably written at Canterbury in the late tenth century; the later addition of obits reveal it was in use in the regular, reformed community at Abingdon by the 1040s. ${ }^{26}$ No surviving martyrological manuscripts have yet been linked to secular communities in eleventh-century England.

Like litanies, historical martyrologies appear on the one hand to be scholarly compilations of accumulated traditions; on the other hand, like calendars as well as litanies, they were generally adapted to incorporate cults local to the house owning them. ${ }^{27}$ These twin features make it very difficult to identify early recensions in the case of many of the earlier martyrological texts, but Usuard's compilation is rather different because an authorial copy still survives. ${ }^{28}$ It is possible therefore to establish its earliest recensions with some certainty, and to identify the entries added to this text later. These additional entries make it more possible to track the textual ancestry of a particular manuscript. Drawing on the surviving copies of Usuard written in England in the tenth, later eleventh and twelfth 
centuries, this article suggests that the mid-twelfth-century copy, now Exeter 3518, is based on an eleventh-century exemplar.

EXETER CATHEDRAL LIBRARY MS 3518: THE MANUSCRIPT, ITS

\section{CONTENTS AND CONTEXT}

Exeter 3518 was made for the canons of Exeter cathedral. The secular cathedral community at Exeter was a new foundation, established by Bishop Leofric (1046-72) after he transferred the see there from Crediton in $1050 .{ }^{29}$ The books copied and owned by the Exeter community in the late eleventh and early twelfth centuries have received a good deal of attention from students of both Old English and Latin culture in this period. ${ }^{30}$ Richard Gameson and Rodney Thomson have each suggested that Exeter's library was, in many ways, typical for a cathedral community at the time, both monastic and secular. ${ }^{31}$ The musicologist Jesse Billett argues that Exeter under Leofric acquired its chant book (the “Leofric Collectar", now London, British Library, MS Harley 2961) from a reformed monastic community, probably that of Winchester; this raises the possibility that Exeter also acquired its martyrology from a reformed monastic community. ${ }^{32}$ This case study is therefore likely to be representative of other regular communities at this time. Focussing on a text used in daily chapter, it aims to redress the current biases in research on the Anglo-Norman cult of saints towards other sorts of narrative hagiography and towards monastic communities. By allowing investigation of the various influences at work for how the cult of saints came to be documented in one late eleventh-century secular community it also opens up fresh ways for understanding the role played by Latin liturgical texts in how and why Anglo-Norman churchmen came to document local cults.

\section{The Manuscript Evidence}

Exeter 3518 is a partial copy in 62 folia of Usuard's Martyrology. It survives in a medieval binding of bare wooden boards (with a more modern loose leather cover); there are 
no flyleaves or pastedowns. ${ }^{33}$ At some point in its history the manuscript lost both its initial and penultimate quires, as well as the outer bifolium of the final quire. Thus the text begins part way through the entry for $8^{\text {th }}$ February instead of on $1^{\text {st }}$ January; the entries between $9^{\text {th }}$ October and $6^{\text {th }}$ December are also missing, as is some text for $31^{\text {st }}$ December. ${ }^{34}$ The main text is written in a formal Romanesque script which exhibits various "West Country" features and dates to the middle decades of the twelfth century; the coloured initials follow the pigments used in other twelfth-century Exeter manuscripts. ${ }^{35}$ It is a medium-sized book, now measuring $220 \times 162 \mathrm{~mm}$ with a written space of $180 \times 100 \mathrm{~mm}$ in 27 long lines. It was seemingly designed to have obits and other notices added to its wide margins, although these have been partially cropped by a later binder. Some 400 obits and notices have been added in many different hands over the course of the twelfth and thirteenth centuries whilst at least seven obits have later been erased. ${ }^{36}$ Several dated obits are written in a hand similar to that which wrote the main text, the latest being that for "Adela, mother of Stephen king of England" (d. 1137) (fol. 6 $6^{\mathrm{v}}$, giving a likely terminus post quem for the manuscript. The location of some of the cults in the main text, and the names of the bishops, cathedral clergy and benefactors in the obits, all suggest that this manuscript was written for and used by the Exeter cathedral chapter.

As mentioned above, Exeter is an eleventh-century foundation. The cathedral was established in 1050 when Leofric obtained papal consent to transfer the seat of the see from Crediton, 8 miles to the north-west, where it had been first established in 909, to the existing church of St Peter on the site of the forum in the Roman city of Exeter. ${ }^{37}$ "Brought up and educated in Lotharingia", in the words of William of Malmesbury, Leofric committed energy and resources to the education of his clergy. "After the Lotharingian pattern", he established the community serving the cathedral as a house of canons following the Rule of Chrodegang, which had been initially popularised under Louis the Pious. ${ }^{39}$ He endowed the 
community with lands, vessels and other ornaments, and books. ${ }^{40}$ In recent years considerable attention has been paid to the ways in which Exeter's first bishop, Leofric, and his two Norman successors, Osbern (1072-1103) and William de Warelwast (1107-37), assembled Exeter's library up to $1125{ }^{41}$ But Exeter 3518's later date has meant that it has commanded relatively little attention, except from specialists in the local cults of Devon and Cornwall. Indeed, when J.N. Dalton published the Exeter Ordinale in 1909, he based his edition of the Exeter martyrology on a later fourteenth-century copy of Usuard commissioned by Bishop John Grandisson (1327-1369), now Cambridge, Corpus Christi College Ms 93 (hereinafter CCCC 93), which omits many local entries. ${ }^{42}$ G. H. Doble recognised its importance for the early history of Cornish cults and published in 1940 the variants in the main text of Exeter 3518 from CCCC 93 as an appendix to J.N.Dalton's 1909 edition of the latter manuscript. ${ }^{43}$ His research has subsequently been taken up by later scholars of early medieval Cornwall and its saints. ${ }^{44}$ More recently David Lepine and Nicholas Orme published the obits as part of their study of Exeter's medieval records for death and memory, and Robert Bartlett drew upon the manuscript very briefly to make some observations about martyrologies as a genre in his recent history of the medieval cult of saints. ${ }^{45}$ There is however, no study of Exeter 3518 as a whole in its historical and cultural context.

The text in Exeter Ms 3518 belongs to the second recension of Usuard's text. ${ }^{46}$ Usuard was a monk of Saint-Germain-de-Près writing in the three decades before his death $c$. 877 , and by the eleventh and twelfth centuries his work had become extremely popular. ${ }^{47} \mathrm{He}$ drew upon the works of his early ninth-century Frankish predecessors to compile the first martyrology to include entries of the saints to be remembered on every day of the year. He recorded some 2000 saints in a piece that is encyclopedic in its scope, combining synthesis with original research. It is in effect a work of salvation history, including entries for some Old Testament prophets and New Testament figures with early Christian apostles and martyrs 
and more recent saints. He ranges from Palestine and the eastern Mediterranean of the early Church to seventh-century England and ninth-century Spain, including details of the Christians martyred at Cordoba in the 850s. The houses owning his text often added more local cults. The end result is a text which links familiar local cults to ones that were more remote, geographically and temporally, to create a work which secured the local church within the wider framework of Christian history.

The careful scholarship of Jacques Dubois demonstrates that Usuard's authorial text survives now in three main recensions:

- The 'primitive' recension, that is the version of the text Usuard completed between 20 October 858 and 20 September 859 . This recension can be dated with such precision because it includes an entry for SS George and Aurelius, whose relics were brought from Cordoba to Paris by Usuard on 20 October 858, but not one for the martyrdom of Bishop Eulogius of Cordoba. Eulogius waskilled on 11 March 859 but Usuard entered his name on 20 September in later recensions, hence the terminus ad quem. This version has so far been identified in twelve manuscripts. ${ }^{48}$

- The first recension represents the version of Usuard's text completed post 20 September 859; it circulated widely within the area covered by the Frankish Empire from the 860 s and now survives in numerous manuscripts from the ninth century onwards. ${ }^{49}$ Dubois suggested that the popularity of this version owed much to royal support. As his own work, together with that of Overgaauw, demonstrates, the first recension was usually introduced by the letter-preface in which Usuard dedicated his work to the Frankish ruler Charles the Bald, setting out his aims in compiling the text and his sources. ${ }^{50}$ This letter-preface was also often followed by an Augustinian text on how the feasts of the apostles and martyrs should be celebrated, known from its 
incipit as Festivitates, which is also found in other ninth-century martyrological texts. $^{51}$

- The second recension represents the version of Usuard's text kept at his own community of Saint-Germain-des-Prés and which he continued to revise between 859 and his death in 877; it now survives in at least 22 manuscripts. It is not accompanied by the letter-preface to Charles the Bald, nor, usually, any other prefatory material. Other than later copies made at and for Saint-Germain-des-Prés, this version circulated mainly in Normandy and England. ${ }^{52}$

At first sight, given the patterns in geographical circulation highlighted above, it is unsurprising to find that the text of Exeter 3518 belongs to the second recension. But it is worth following the implications of this further for the second recension seems to have come to England first, not via Normandy after the Conquest, but rather sometime in the tenth century via Flanders. The earliest surviving manuscript of Usuard with an English provenance is CCCC 57. ${ }^{53}$ This is a monastic chapter book, containing a copy of the Rule of Benedict, alongside the text of the second recension (without the prefaces), and various other texts associated with the Aachen monastic reforms of the early ninth century. Timothy Graham and Mechtild Gretsch have both studied this manuscript in detail without focusing on the martyrology in particular. Whilst the later addition of obits reveals that it was in use at the monastery of Abingdon by the 1040s, Richard Gameson suggests it was not copied there, but rather probably written at Christ Church, Canterbury, in the late tenth century on the grounds of both script - the use of the same monumental display script as is found in other Canterbury manuscripts - and interpolations into the text of the Benedictine Rule which are also found in a mid-eleventh-century manuscript, with an early provenance from Christ Church, Canterbury. ${ }^{54}$ Its original martyrological text is remarkably close to that in the late ninthcentury Saint-Germain-des-Près copy of the second recension, with only six modifications to 
that version; some twenty-one cults, mostly southern English or Flemish, were subsequently added in Anglo-Saxon hands in blank spaces and margins. Gretsch therefore suggested that CCCC 57 was perhaps based on a continental exemplar brought back to Glastonbury by the monastic reformer Dunstan from his exile in Flanders in the 940s for various reasons in which the evidence from the martyrology plays only a minor part. Gretsch's principle argument for attributing CCCC 57's exemplar to Dunstan is based first around the overall theme of the contents of the manuscript and its interest in the text of the Rule of Benedict, as mediated by the Anianian reforms of the early ninth century; secondly, she suggests that because the names of various cults associated with the tenth-century English reformers were added in later hands to the main text of the martyrology that it was based on a copy which predates their deaths. Following David Dumville, she attributes the manuscript to Glastonbury because it replaces Usuard's reference to St Patrick of Nevers with a reference to the Irish St Patrick on 24 August, whose cult is recorded at Glastonbury. ${ }^{55}$ Gretsch's arguments have subsequently been amplified by Merete Geert Andersen's analysis of the five other cults added to Usuard's text by the original scribe of CCCC 57 which point to St Peter's Ghent, Toul, Glastonbury and Wimborne, and similarly fit with Dunstan's career as abbot of Glastonbury and archbishop of Canterbury. ${ }^{56}$ Glastonbury claimed the relics of two of these five additional cults: those of St Aidan, first bishop of Lindisfarne ( $31^{\text {st }}$ August), and St Cuthbert whose translation was recorded in the martyrology on $4^{\text {th }}$ September. A further two of these entries seemingly point to the origins of CCCC 57's exemplar in the Low Countries: St Ansbert of Rouen ( $9^{\text {th }}$ February), whose relics were brought to St Peter's, Ghent in 944 , and St Mansuetus of Toul ( $2^{\text {nd }}$ September). The final entry relates to St Cuthburga of Wimborne (Dorset), whose feast is found in three English calendars from before $1100 .^{57}$ CCCC 57 is the only copy of any version of Usuard to survive from Anglo-Saxon England; the next earliest English manuscripts both date from the turn of the twelfth century: 
- Durham, Cathedral Library, Ms B.IV.24 (Durham, s. xi/xii); this is a copy of Usuard's first recension and survives in a chapter book with the Rule of Benedict and a copy of Lanfranc's Constitutions amongst other texts.

- $\quad$ London, British Library, Ms Cotton Vitellius C.xii, fols. 114-57 (St Augustine's, Canterbury, s.xi/xii); this is a copy of Usuard's second recension. ${ }^{58}$

Andersen has published a handlist of thirty-two medieval manuscripts of Usuard with an English provenance now surviving in British libraries; nineteen of these are copies of the second recension, and three other late medieval manuscripts represent what Andersen categorised as a mixed tradition of first and second recensions. ${ }^{59}$ Both she and Michael Lapidge have postulated that other copies of Usuard must have circulated within eleventhcentury England. ${ }^{60}$ Andersen further suggests that the Canterbury origins of CCCC 57 help to explain how and why the second recension became so dominant in later medieval England. ${ }^{61}$ But in the absence of other pre-Conquest manuscripts, the early history of the circulation of Usuard within England, and the role of Canterbury in this, remains unclear.

Investigation of the context in which these two late eleventh-century copies were made helps highlight what is distinctive about that for Exeter 3518. Like Abingdon, and unlike Exeter, Durham and St Augustine's were both Benedictine communities, although Durham had only recently become one at the time it acquired its martyrology. ${ }^{62}$ The chapter at Durham cathedral was reformed as a monastic community under its Norman Bishop William de Calais in 1083, just over thirty years after Exeter was established as a canonical community under Bishop Leofric. ${ }^{63}$ In other ways the cathedral churches of late eleventhcentury Durham and Exeter are very similar, for both witnessed the rapid growth of their libraries under their initial reforming bishop and, in Exeter's case, their immediate successors; by contrast Abingdon and St Augustine's, as older and more established monastic communities, did not experience the same spike in acquisitions. But Durham is exceptional 
in acquiring the earliest surviving English copy of the first recension of Usuard: why did Exeter not acquire this recension of the text? Here Thomson's observation that Exeter's bibliographical acquisitions in this period lack the Normanness of the Durham collection assembled at the same time is helpful. ${ }^{64}$ Durham's later monastic turn meant it had a more pressing need to conform to the mainstream of European practice than the secular community at Exeter. St Augustine's, by contrast, as a more established community - albeit one drawn into occasional conflict with Lanfranc - is more likely to have drawn on existing English traditions for its copy of the second recension, which privileged Augustine and his companions and the early bishops of Canterbury amongst its additional entries. ${ }^{65}$

Exeter 3518 was written at Exeter in the middle decades of the twelfth century but is it a copy of a text new to Exeter at that point or a later copy of one already known in Exeter? And if so, when did Exeter's canons first acquire a copy of Usuard's text? Exeter 3518 is a copy of the second recension, but there is other evidence which suggests that by the late eleventh century the Exeter community was also aware of the text of the first recension: this is the manuscript now Cambridge, Corpus Christi College, Ms 201 (hereinafter CCCC 201), pp. 179-272. ${ }^{66}$ CCCC 201 is a compilation assembled by Archbishop Parker in the sixteenth century, who added this final section to a collection of devotional and homiletic material copied at New Minster, Winchester in the first half of the eleventh century. This final section includes a copy of Bishop Theodulf of Orléans's episcopal Capitulary in Latin and Old English and a homily in Old English, both written in the same scriptorium which copied other manuscripts for Bishop Leofric in the third quarter of the eleventh century; this is generally assumed by scholars to have been based at Exeter. The homily concludes on the first outer leaf of a bifolium; a later eleventh-century hand, seemingly also based at Exeter, added the text of Usuard's letter-preface to Charles the Bald and part of the Festivitates preface on the inner sides of the bifolium (CCCC 201, pp. 260-61). The Festivitates text must therefore 
seemingly have been always incomplete for the final verso folio of this bifolium has been left blank. ${ }^{67}$ As we have already noted, this prefatory material is only associated with copies of the first recension of Usuard's text, the earliest surviving English manuscript of which is that made for Durham in the 1090s. It may of course be only coincidence that the Usuard material in CCCC 201 was copied at around the same time as the Durham manuscript, but we have to ask why the Exeter scribe wrote only a partial text? This bifolium may represent an interest in a new version of a text which was already familiar to its copyist who naturally, therefore, focussed on the most distinctive aspects of what distinguished the first from the second recension. In other words, CCCC 201 raises the possibility that the second recension was already known at Exeter in the late eleventh century.

There are other grounds for this hypothesis. In the inventory of books and other items Leofric gave to his cathedral community mention of the martyrologium follows immediately after the regula canonicum. ${ }^{68}$ The combination of Rule and Martyrology are commonly found together in codices generally known as medieval chapter books because extracts from both texts were recited daily in chapter. ${ }^{69}$ Neil Ker therefore suggested that the surviving bilingual version of the Enlarged Rule for Canons of Chrodegang, now Cambridge, Corpus Christi College, Ms 191 (hereinafter CCCC 191), which was copied at Exeter under Leofric, was originally produced as a companion volume to a now lost Latin martyrology and a surviving copy of the vernacular Old English Martyrology, now Cambridge, Corpus Christi College, Ms 196 (hereinafter CCCC 196). ${ }^{70}$ Ker further suggested that CCCC 191 was not only linked to CCCC 196 but also to the Exeter section of CCCC $201 .^{71}$ Others have followed him in linking this Old English Martyrology manuscript to Exeter's bilingual copy of Chrodegang's Rule. ${ }^{72}$ But Gneuss observed that although the term martyrologium was used of both Latin and vernacular texts in Anglo-Saxon England, its use in the Leofric inventory "probably also denotes the Latin book for the chapter office". ${ }^{73}$ Although he did 
not set out any further grounds for his judgement, it is odd that the Enlarged Rule, seemingly listed in Latin in the inventory, existed in both Latin and Old English but we have no surviving eleventh-century Latin text of a martyrology to accompany the Old English text. ${ }^{74}$ The version of the Rule of Chrodegang known at Exeter provided that each day in chapter after the lesson for the day the saints to be remembered should be announced. ${ }^{75}$ But the Old English Martyrology is unsuitable for this purpose, and it is unlikely that it functioned as a chapter book. Indeed its most recent editor, Christine Rauer, has argued, on the grounds that its textual structure is very different from that of other martyrologies, that it was unsuitable for use in chapter: "the communal or ceremonial reading which other martyrologies experienced seems less likely in the case of the Old English Martyrology". ${ }^{76}$ A second partial and error-ridden text of the Old English Martyrology copied into the margins of a vernacular translation of Bede's Historia Ecclesiastica was also in Exeter by the late eleventh century, and suggests that this book would have been read privately at Exeter rather than in chapter. ${ }^{77}$ The final piece of evidence Ker adduced for his thesis that the Bilingual Rule of Chrodegang was accompanied by both a Latin and Old English martyrology is the entry in the 1327 inventory of Exeter's library which lists among the service books a "Martirologium Latinum et Anglicum: Circumcisio". ${ }^{78}$ As "Circumcisio" is the incipit for the second recension of Usuard, Ker suggested that Leofric originally had a Latin martyrology to sit alongside his Latin rule. It might even be a reference to Exeter 3518 before the initial quire went missing, suggesting that in the fourteenth century it was bound with a vernacular martyrology. It is not, however, obvious that it refers to the Old English Martyrology. The wording refers to a single "martyrology" in two languages, not to two very different martyrological texts. It is in any case unlikely that it refers to a time when Exeter 3518 was bound with the Old English Martyrology now in CCCC 201 as the measurements of the two codices make this improbable. $^{79}$ The evidence reviewed so far, therefore raises, the possibility that the second 
recension of Usuard might have been known in Exeter since at least the late eleventh century but it is far from conclusive.

Indeed, Usuard's text might not have been introduced under Bishop Leofric but rather under one of his Norman successors: Bishop Osbern, Bishop William de Warelwast, or his nephew, Bishop Robert de Warelwast (1138-55). Leofric's two immediate successors were both closely linked to the royal household, but also had strong links to Normandy. Bishop Osbern's father was a member of the ducal household, although Osbern himself joined the court of Edward the Confessor whilst Edward was in exile in Normandy, before transferring to the court of William in 1066; Bishop William de Warelwast also came from Normandy, before joining the court of William Rufus, and he was succeeded in turn by his nephew, Robert. ${ }^{80}$ The second recension text could therefore have been brought to Exeter directly from Normandy which was the region, other than England, where this version circulated most widely. Whilst Leofric ensured that his reformed clergy had the necessary service books, Bishop William appears to have been specifically interested in saints and introducing Norman texts about them to his cathedral's canons: the 1327 inventory lists some twelve works bequeathed by 'Bishop William' de Warelwast, including two collections of hagiography according to the 'Use of Rouen': “Communis Liber Sanctorum de Usu Rotomagensi” and "Unus Liber Sanctorum de eodem Usu". 81 Other evidence, however, points to Bishop William's interest in his more immediate locality: Stephen Marritt has suggested that charters issued by the chapter under Bishop William testify to an interest in Exeter's Anglo-Saxon past in the $1120 \mathrm{~s}^{82}$ The manuscript evidence therefore suggests that it is highly likely that a copy of the second recension of Usuard was known in Exeter by the late eleventh century, but whether it was introduced by Leofric or one of his two immediate successors, and in particular whether it was based on an English or Norman model, requires the further investigation of the text of Exeter 3518. 


\section{The Evidence of Anglo-Saxon Cults}

In order to help resolve these questions we must therefore investigate Exeter 3518's text and in particular a sample from the almost one hundred additional entries included in the main text that do not appear in the Saint-Germain-de-Près 'authorial' manuscript of Usuard's second recension. Additional cults in martyrologies, like those in litanies, generally constitute records of textual transmission. In order to help locate the model for Exeter 3518, the additions have been compared to six other English manuscripts from the eleventh and twelfth centuries of Usuard's text; for further context the evidence for knowledge of these cults in English calendars from before 1100 has also been included. This comparison suggests that the additions to Exeter 3518 are clearly grounded in tenth- and eleventh-century English traditions. As Table 1 demonstrates, Exeter 3518 is exceptional amongst nearcontemporary English martyrological manuscripts in including five out of the six additional (to Usuard's original text) entries included in the main text of the tenth-century Anglo-Saxon copy, now CCCC 57 (but not the alterations to the text for St Patrick noted above). The calendar evidence for the cults added into the main text of CCCC 57 suggests that, with the exception of the widespread cult of the translation of Cuthbert, knowledge of these cults was confined mainly to Canterbury and western England. Thus Aidan features in calendars from Christ Church, Canterbury (later at Exeter); Wilton; Sherborne; Evesham (or possibly Worcester); and Wells. ${ }^{83}$ Cuthberga appears in calendars from Canterbury (or Glastonbury), Sherborne, and New Minster, Winchester. ${ }^{84}$ The two Lotharingian cults (Ansbert in Ghent and Mansuetus in Toul) only otherwise feature in a calendar in a collection associated with Bishop Giso of Wells. ${ }^{85}$ Bishop Leofric, like Giso, was educated in Lotharingia and his own life therefore offers another conduit by which these two cults entered Exeter 3518; this is a point to which we return below as these are not the only additional cults from the empire in this manuscript. ${ }^{86}$ 


\begin{tabular}{|c|c|c|c|c|c|c|c|c|}
\hline Feast & $\begin{array}{l}\text { Entry } \\
\text { in } \\
\text { numb } \\
\text { er of } \\
\text { Englis } \\
\text { h } \\
\text { calend } \\
\text { ar } \\
\text { before } \\
1100\end{array}$ & $\begin{array}{l}\text { CCCC 57 } \\
\left(\text { s.x } x^{\text {ex }} \text {; }\right. \\
\text { Christ } \\
\text { Church, } \\
\text { Canterbu } \\
\text { ry, } 2^{\text {nd }} \\
\text { recension } \\
\text { ) }\end{array}$ & $\begin{array}{l}\text { Durham,Cathe } \\
\text { dral Library } \\
\text { Ms B.IV.24 } \\
\text { (s. xi }^{\text {ex }} \\
\text { Durham, } 1^{\text {st }} \\
\text { recension) }\end{array}$ & $\begin{array}{l}\text { London, } \\
\text { British } \\
\text { Library, } \\
\text { Ms } \\
\text { Cotton } \\
\text { Vitellius } \\
\text { C. xii (s. } \\
\text { xi }^{\text {ex }} / \mathbf{s . x i i} \\
\text { ) (St } \\
\text { Augustin } \\
\text { e's } \\
\text { Canterbu } \\
\text { ry, 2 } \text { 2d }^{\text {nd }} \\
\text { recension } \\
\text { ) } \\
\end{array}$ & $\begin{array}{l}\text { London, } \\
\text { British } \\
\text { Library, } \\
\text { Ms Royal } \\
\text { 7.E.vi } \\
\text { (s. xii, } \\
\text { Christ } \\
\text { Church, } \\
\text { Canterbu } \\
\text { ry, } 2^{\text {nd }} \\
\text { recension } \\
\text { ) }\end{array}$ & $\begin{array}{l}\text { Exeter, } \\
\text { Exeter } \\
\text { Cathed } \\
\text { ral } \\
\text { Library } \\
\text {, Ms } \\
3518 \\
\text { (s. } \\
\text { xii }^{\text {med }} \text {, } \\
\text { Exeter, } \\
2^{\text {nd }} \\
\text { recensi } \\
\text { on) }\end{array}$ & $\begin{array}{l}\text { Londo } \\
\text { n, } \\
\text { British } \\
\text { Librar } \\
\text { y, Ms } \\
\text { Royal } \\
\text { 2.A.xiii } \\
\text { (south- } \\
\text { west } \\
\text { Englan } \\
\text { d, 1220 } \\
\text { x 1224) }\end{array}$ & $\begin{array}{l}\text { Oxford, } \\
\text { Bodleian } \\
\text { Library, } \\
\text { Ms } \\
\text { Rawlinso } \\
\text { n D 1225 } \\
\text { (St } \\
\text { Chad's, } \\
\text { Shrewsbu } \\
\text { ry, s. xii) }\end{array}$ \\
\hline $\begin{array}{l}\text { Feb. } 9^{\text {th }}: \\
\text { Ansbert } \\
\text { of } \\
\text { Rouen }\end{array}$ & $\begin{array}{l}1 \\
\text { (Wells }\end{array}$ & $\checkmark$ & -- & -- & $\checkmark$ & $\checkmark$ & $\checkmark$ & $\checkmark$ \\
\hline $\begin{array}{l}\text { Aug. } \\
31^{\text {st: }} \\
\text { Aidan of } \\
\text { Lindisfa } \\
\text { rne }\end{array}$ & 6 & $\checkmark$ & $\begin{array}{l}\checkmark \text { (added in } \\
\text { margin early s. } \\
\text { xii hand on fol. } \\
31 \mathrm{r})\end{array}$ & $\checkmark$ & $\checkmark$ & $\checkmark$ & $\checkmark$ & -- \\
\hline $\begin{array}{l}\text { Aug. } \\
31^{\text {st }}: \\
\text { Cuthber } \\
\text { ga of } \\
\text { Wimbor } \\
\text { ne }\end{array}$ & 3 & $\checkmark$ & -- & $\checkmark$ & -- & $\checkmark$ & $\begin{array}{l}\checkmark \text { (adde } \\
\mathrm{d} \\
\text { afterwa } \\
\text { rds in } \\
\text { similar } \\
\text { hand) }\end{array}$ & -- \\
\hline $\begin{array}{l}\text { Sept. } 3^{\text {rd }} \text { : } \\
\text { Mansuet } \\
\text { us of } \\
\text { Toul }\end{array}$ & $\begin{array}{l}1 \\
\text { (Wells }\end{array}$ & $\begin{array}{l}\checkmark\left(2^{\text {nd }}\right. \\
\text { Septembe } \\
\text { r) }\end{array}$ & $\checkmark$ & -- & -- & $\checkmark$ & -- & -- \\
\hline $\begin{array}{l}\text { Sept. } 4^{\text {th }}: \\
\text { Translati } \\
\text { on of } \\
\text { Cuthbert }\end{array}$ & 13 & $\checkmark$ & $\begin{array}{l}\checkmark \text { (added in } \\
\text { early s. xii hand } \\
\text { to main text fol. } \\
\text { 31r) }\end{array}$ & $\checkmark$ & -- & $\checkmark$ & $\checkmark$ & $\checkmark$ \\
\hline
\end{tabular}

Table 1: A Comparison Of The ‘Additional Entries' In The Main Text Of CCCC 57 With

Other English Manuscripts Of Usuard From The Eleventh And Twelfth Centuries.

Further, as Table 2 demonstrates, Exeter 3518 is also exceptional in including all but one of the entries added into CCCC 57 later in the Anglo-Saxon period. Exeter 3518 is, therefore, established upon tenth- and eleventh-century English traditions. Unlike the earlier CCCC 57, it memorialises within its main text all the leading bishops of the tenth- and early eleventh-century reform movement: Oswald, Ælfheah, Dunstan, Wulfsige and Æthelwold. ${ }^{87}$ 
The calendrical and martyrological evidence in Table 2 also suggests that the cults for these figures were widely known across southern England before the end of the eleventh century. Other cults associated with the reformers of the late Anglo-Saxon Church in Exeter 3518 which can be widely found in both the martyrological and calendrical material from this period include those for Saint Edward, king and martyr, his sister Edith, Saints Swithun, Kenelm and Neot. ${ }^{88}$ The presence of this material in Exeter 3518 testifies to the fact that it was based upon English traditions but does not help us to identify or date its exemplar more precisely.

\begin{tabular}{|c|c|c|c|c|c|c|c|c|}
\hline Feast & $\begin{array}{l}\text { Entry } \\
\text { in } \\
\text { numb } \\
\text { er of } \\
\text { Englis } \\
\text { h } \\
\text { calend } \\
\text { ar } \\
\text { before } \\
1100\end{array}$ & $\begin{array}{l}\text { CCCC 57 } \\
\left(\text { s.x }{ }^{\text {ex }} \text {; }\right. \\
\text { Christ } \\
\text { Church, } \\
\text { Canterbu } \\
\text { ry, } 2^{\text {nd }} \\
\text { recension } \\
\text { ) }\end{array}$ & $\begin{array}{l}\text { Durham,Cathe } \\
\text { dral Library } \\
\text { Ms B.IV.24 } \\
\text { (s. xi }^{\text {ex }} \text {, } \\
\text { Durham, } 1^{\text {st }} \\
\text { recension) }\end{array}$ & $\begin{array}{l}\text { London, } \\
\text { British } \\
\text { Library, } \\
\text { Ms } \\
\text { Cotton } \\
\text { Vitellius } \\
\text { C. xii (s. } \\
\text { xi }^{\text {ex }} / \mathbf{s . x i i} \\
\text { ) (St } \\
\text { Augustin } \\
\text { e's } \\
\text { Canterbu } \\
\text { ry, 2nd } \\
\text { recension }\end{array}$ & $\begin{array}{l}\text { London, } \\
\text { British } \\
\text { Library, } \\
\text { Ms Royal } \\
\text { 7.E.vi } \\
\text { (s. xii, } \\
\text { Christ } \\
\text { Church, } \\
\text { Canterbu } \\
\text { ry, } 2^{\text {nd }} \\
\text { recension } \\
\text { ) }\end{array}$ & $\begin{array}{l}\text { Exeter, } \\
\text { Cathed } \\
\text { ral } \\
\text { Library } \\
\text {, Ms } \\
3518 \\
\text { (s. } \\
\text { xii }^{\text {med }}, \\
\text { Exeter, } \\
2^{\text {nd }} \\
\text { recensi } \\
\text { on) }\end{array}$ & $\begin{array}{l}\text { Londo } \\
\text { n, } \\
\text { British } \\
\text { Librar } \\
\text { y, Ms } \\
\text { Royal } \\
\text { 2.A.xii } \\
\text { i } \\
\text { (south- } \\
\text { west } \\
\text { Engla } \\
\text { nd, } \\
\mathbf{1 2 2 0} x \\
\text { 1224) }\end{array}$ & $\begin{array}{l}\text { Oxford, } \\
\text { Bodleian } \\
\text { Library, } \\
\text { Ms } \\
\text { Rawlinso } \\
\text { n D 1225 } \\
\text { (St } \\
\text { Chad's, } \\
\text { Shrewsbu } \\
\text { ry, s. } \\
\text { xii) }\end{array}$ \\
\hline $\begin{array}{l}\text { Feb. } 28^{\text {th }} \\
\text { Archbish } \\
\text { op } \\
\text { Oswald } \\
\text { of } \\
\text { Worcest } \\
\text { er }\end{array}$ & 6 & $\checkmark$ & -- & -- & -- & $\checkmark$ & $\checkmark$ & $\checkmark$ \\
\hline $\begin{array}{l}\text { March } \\
2^{\text {nd }} \\
\text { Chad }\end{array}$ & & $\checkmark$ & $\checkmark$ & $\checkmark$ & $\checkmark$ & $\checkmark$ & $\checkmark$ & $\checkmark$ \\
\hline $\begin{array}{l}\text { March } \\
18^{\text {th }} \\
\text { King } \\
\text { Edward } \\
\text { the } \\
\text { Martyr }\end{array}$ & & $\checkmark$ & $\checkmark$ & $\checkmark$ & $\checkmark$ & $\checkmark$ & $\checkmark$ & $\checkmark$ \\
\hline $\begin{array}{l}\text { April } \\
19^{\text {th }} \\
\text { Ælfheah }\end{array}$ & 15 & $\checkmark$ & $\checkmark$ & $\checkmark$ & $\checkmark$ & $\checkmark$ & $\checkmark$ & -- \\
\hline $\begin{array}{l}\text { May } 2^{\text {nd }} \\
\text { Bertin }\end{array}$ & & $\checkmark$ & -- & -- & -- & $\checkmark$ & -- & -- \\
\hline May $19^{\text {th }}$ & 21 & $\checkmark$ & $\checkmark$ & $\checkmark$ & $\checkmark$ & $\checkmark$ & $\checkmark$ & -- \\
\hline
\end{tabular}




\begin{tabular}{|c|c|c|c|c|c|c|c|}
\hline Dunstan & & & & & & & \\
\hline $\begin{array}{l}\text { June } 16^{\text {th }} \\
\text { Bertin }\end{array}$ & $\checkmark$ & - & $\begin{array}{l}\text { Quire } \\
\text { missing }\end{array}$ & - & - & - & - \\
\hline $\begin{array}{l}\text { July } 2^{\text {nd }} \\
\text { Swithun }\end{array}$ & $\checkmark$ & $\checkmark$ & $\begin{array}{l}\text { Quire } \\
\text { missing }\end{array}$ & $\checkmark$ & $\checkmark$ & $\checkmark$ & $\checkmark$ \\
\hline $\begin{array}{l}\text { July } 8^{\text {th }} \\
\text { Grimbal } \\
\text { d }\end{array}$ & $\checkmark$ & -- & $\begin{array}{l}\text { Quire } \\
\text { missing }\end{array}$ & $\checkmark$ & $\checkmark$ & $\checkmark$ & $\checkmark$ \\
\hline $\begin{array}{l}\text { July } 15^{\text {th }} \\
\text { Swithun }\end{array}$ & $\checkmark$ & $\checkmark$ & -- & -- & $\checkmark$ & $\checkmark$ & $\checkmark$ \\
\hline $\begin{array}{l}\text { July } 17^{\text {th }} \\
\text { Kenelm }\end{array}$ & $\checkmark$ & $\checkmark$ & $\checkmark$ & -- & $\checkmark$ & $\checkmark$ & $\checkmark$ \\
\hline $\begin{array}{l}\text { Sept. } \\
16^{\text {th }} \\
\text { Eadburg } \\
\text { h }\end{array}$ & $\checkmark$ & -- & $\checkmark$ & -- & $\checkmark$ & $\checkmark$ & -- \\
\hline $\begin{array}{l}\text { Oct. } 19^{\text {th }} \\
\text { Frideswi } \\
\text { de }\end{array}$ & $\checkmark$ & -- & -- & -- & $\begin{array}{l}\text { Quire } \\
\text { missing }\end{array}$ & $\checkmark$ & $\checkmark$ \\
\hline $\begin{array}{l}\text { Nov. } \\
20^{\text {th }} \\
\text { Edmund }\end{array}$ & $\checkmark$ & -- & -- & $\checkmark$ & $\begin{array}{l}\text { Quire } \\
\text { missing }\end{array}$ & $\checkmark$ & $\checkmark$ \\
\hline $\begin{array}{l}\text { Dec. 3rd } \\
\text { Birinus }\end{array}$ & $\checkmark$ & -- & - & -- & $\begin{array}{l}\text { Quire } \\
\text { missing }\end{array}$ & $\checkmark$ & $\checkmark$ \\
\hline $\begin{array}{l}\text { Dec. } 7^{\text {th }} \\
\text { Ordinati } \\
\text { on of } \\
\text { Ambrose }\end{array}$ & $\checkmark$ & -- & -- & -- & $\checkmark$ & -- & -- \\
\hline $\begin{array}{l}\text { Dec. } 13^{\text {th }} \\
\text { Judoc }\end{array}$ & $\checkmark$ & -- & -- & $\checkmark$ & $\begin{array}{l}\left(23^{\text {rd }}\right. \\
\text { June })\end{array}$ & $\checkmark$ & $\checkmark$ \\
\hline
\end{tabular}

Table 2: A Comparison Of The Entries Added Later In The Anglo-Saxon Period To CCCC

57 With Other English Manuscripts Of Usuard From The Eleventh And Twelfth Centuries

CCCC 57 was not, however, the model for Exeter 3518. As the comparison of the texts of a sample of entries in the Appendix reveals, there is considerable variation in the wording of entries across the different martyrological manuscripts. It suggests that there was not a single exemplar for these changes, and, pace Andersen, Christ Church Cathedral, Canterbury is unlikely therefore to be the source of all these copies of Usuard. Rather these differences indicate the circulation of a much larger number of manuscripts than now survive, each presumably being updated according to local calendars. But it is also possible to reach some firmer conclusions about Exeter 3518. It is clearly grounded in cults which came to the fore in the late Anglo-Saxon period, suggesting its possible roots in an earlier exemplar. At the 
same time, as the examples given in the Appendix demonstrate, the compiler of Exeter 3518 was unique amongst his English contempories in locating the subjects of these supplementary entries in Great Britain ("in brittannia maiori”) rather than just in Britain ("in brittannia"). Usuard had not felt any need to distinguish Britain from Brittany when recording British cults so this qualification may be deliberate. ${ }^{90}$ It is at least possible that Exeter 3518 may have been prepared for a Lotharingian or, perhaps more likely, Norman audience of clerics already familiar with Britanny and for whom such a distinction would be helpful when introduced to new cults whilst listening to, and reading aloud from the martyrology. ${ }^{91}$ If not all early English copies of Usuard came from Christ Church, Canterbury, nevertheless the inclusion of certain entries suggests Exeter 3518's debt to that church and hint at a possible date in the late eleventh century. Several apparent errors in the entries for the eighth-century Saints Eadburh of Lyminge and her sister Mildburh point to disputes over the possession of their relics by rival communities in post-Conquest Canterbury. Two entries in Exeter 3518 read: "In Great Britain in the province of Kent in the place which is called Lyminge [the feast of] the virgin Saint Eadburh"(15 June); "The translation of Saint Eadburh" (18 July). ${ }^{92}$ As Canon Doble pointed out, the compiler of Exeter 3518 (or of his model) had seemingly confused two saints called Eadburh. ${ }^{93}$ The feast more usually commemorated on 15 June is that of the tenth-century Saint Eadburh of Nunnaminster, Winchester, daughter of King Edward the Elder. ${ }^{94}$ From the twelfth century onwards Eadburh of Lyminge (Kent), an eighth-century abbess of Minster-in-Thanet, was usually commemorated on $13^{\text {th }}$ December, or sometimes in November; there is no earlier evidence for her cult. ${ }^{95}$ The compiler of Exeter 3518 also made another apparent error; in the entry for $13^{\text {th }}$ July he recorded the cult of Saint Mildrith, Eadburh's predecessor as abbess of Minster-in-Thanet, but placed her at Wenlock in Shropshire. ${ }^{96}$ In doing so the compiler seems to have confused Mildrith with her sister, Mildburh whose cult was located at Wenlock from at least the late ninth century and usually 
observed on $23^{\text {rd }}$ February, occasionally on $25^{\text {th }}$ June. $^{97}$ Mildrith's feast is generally $12^{\text {th }}$ or $13^{\text {th }}$ July. $^{98}$ Whilst Mildburh herself is recorded in Exeter 3518 under 23 February, as in three late Anglo-Saxon calendars, the Exeter compiler gave no location for her cult. ${ }^{99}$ The calendars confirm that, unlike Saint Eadburh of Lyminge, Saints Mildrith and to a lesser extent her sister, Mildburh, were widely commemorated in later Anglo-Saxon England. Eadburh of Lyminge's cult, however, came to the fore only after her relics, alongside those of Mildrith, were translated in 1085 by Archbishop Lanfranc from Lyminge, having been taken there for safety during Viking raids, to his new foundation, St Gregory's Priory, Canterbury. ${ }^{100}$ The community of St Gregory's possession of Mildrith was contested by St Augustine's, Canterbury who claimed that Mildrith's relics had already been translated to their church from their original location in Thanet in 1030. That the details of these three closely connected cults had become muddled in MS 3518 is perhaps best explained as being due to the oral updating of an existing text in the light of recent cultic developments, rather than any attempt to reconcile two contradictory written accounts, whilst the mention of Lyminge may hint that this element of Exeter 3518 has its origins in the archbishop's circle in late eleventh-century Canterbury, rather than that of St Augustine's.

The Evidence of Eleventh-and Twelfth-century Continental Cults

Other entries also point to a cultic layer in Exeter 3518 from the late eleventh or early twelfth century which could have reached Exeter either directly from Normandy or via Canterbury. An entry on May $9^{\text {th }}$ refers to the translation of the relics of St Nicholas in 1087 from Myra in Anatolia to Bari in Italian Apulia. ${ }^{101}$ Late eleventh- and early twelfth-century Norman monasteries played an important role in the dissemination of John of Bari's account of the translation, and the collections of miracles worked at his new tomb. ${ }^{102}$ The cult could have come to Exeter direct from Normandy: both Leofric's immediate successors as bishops of Exeter, Osbern and William de Warelwast, had strong connections to Normandy. ${ }^{103}$ It is, 
however, also possible that his cult was mediated via Canterbury; the Norman monastery of Bec was central to the dissemination of Nicholas's miracle collection and Anselm of Bec, Archbishop of Canterbury (1093-1109), attended Urban II's council held in 1198 at the shrine of St Nicholas of Bari, and composed a prayer to St Nicholas. Exeter could also have acquired direct knowledge of the cult from the papal court: William de Warelwast, later bishop of Exeter, was in Rome shortly afterwards as the King's representative in the dispute with Anselm. This feast was added in slightly later hands to the texts of both the Durham and St Chad's, Shrewsbury martyrologies, but is not found in the Christ Church, Canterbury martyrology; if it has a Canterbury origin it is a later twelfth-century one. ${ }^{104}$

Another strand, however, suggests a clearer connection between Exeter 3518 and Normandy. Exeter 3518 includes two feasts for St Audoenus, the seventh-century bishop of Rouen and patron of the abbey of St-Ouen, Rouen. The date of his main feast, on 24 August, was widely recorded in early medieval Frankia and England, and his entry on this date in Exeter 3518 is copied word for word from Usuard's text. ${ }^{105}$ However, Exeter 3518 concludes its entry for 14 May with mention of a second feast which is not in Usuard: "In the city of Rouen the ordination of Saint Audoenus bishop and confessor". ${ }^{106}$ There is no evidence, calendrical or otherwise, that this May feast was otherwise known in England in the eleventh century; however, it is noted in two Rouen calendars, both from St-Ouen, which date from the late eleventh and twelfth-centuries respectively. ${ }^{107}$ And Bishop William de Warelwast's gift of two "Libri sanctorum de Usu Rotomagensis" to Exeter cathedral, noted above, offers a direct conduit by which knowledge of this particular aspect of St-Ouen's cult might have been transmitted to Exeter sometime in the first third of the twelfth century. ${ }^{108}$ Whilst there is a tradition that the cult and life of St Audoenus were known at Christ Church, Canterbury from the mid-tenth century onwards, when his relics were seemingly translated there from Rouen, unfortunately all the evidence for the early period comes from the early twelfth 
century and from a time when the ownership of his relics had become contentious within England. ${ }^{109}$ The personal as well liturgical connections between early twelfth-century Exeter and Rouen - Bishop William took his name from a village on the demesne of another abbey in the diocese of Rouen - therefore provide the more convincing explanations for the inclusion of the cult of Saint Audoenus' ordination in Exeter 3518. ${ }^{110}$

Clearly some additions should be linked to Bishop William de Warelwast's early twelfth-century episcopate, but there are also various features of Exeter 3518 which indicate its debt to cults introduced to Exeter from the empire during Bishop Leofric's pontificate in the third quarter of the eleventh century. The mention of the Lotharingian cults of Symeon of Trier (d. 1035) $\left(1^{\text {st }}\right.$ June), Odwulf of Utrecht $\left(12^{\text {th }}\right.$ June) and Eucharius of Trier $\left(8^{\text {th }}\right.$ December), may be linked to the fact he was brought up there. ${ }^{111}$ Similarly, the inclusion of other recent cults from the empire may also be associated with Exeter's founding bishop: Bishop Heribert of Cologne (d. 1021) (16 ${ }^{\text {th }}$ March); Bishop Udalrich of Augsburg (d. 973) ( $\left.4^{\text {th }} \mathrm{July}\right)$; Wencelas of Bohemia (d. 935) $\left(28^{\text {th }}\right.$ September); and Alexius in Rome (17 ${ }^{\text {th }}$ July), whose cult was closely associated with Otto III (d. 1002). ${ }^{112}$ Whilst Odwulf's relics were translated to Evesham in 1030, none of these cults is mentioned in the other surviving English martyrologies with the exception of Heribert. ${ }^{113}$ He features only in the Durham martyrology; the wording there is different to that in Exeter 3518, indicating these entries are independent of each other. ${ }^{114}$ None of these cults feature in any surviving eleventh-century English calendars either. ${ }^{115}$ Only one English litany from this period features four of these saints: Symeon, Odwulf, Udalrich, and Eucharius. It is in a psalter copied at Exeter under Bishop Leofric, now London, British Library, Ms Harley 863. ${ }^{116}$ This litany is one of the longest to survive from Anglo-Saxon England, mentioning around three hundred saints by name. Michael Lapidge therefore described it as a "scholarly compilation". ${ }^{117}$ It is a testament to the interest shown by the Exeter community under its first bishop in collecting 
information about saints from across the Christian world. The encyclopedic nature of Usuard's text, and the additions to it in Exeter 3518, also fits into this intellectual context very well.

The presence of another more recent European cult can be more securely linked to the interests of the church of Exeter and to the pontificate of Bishop Leofric or perhaps his successors. The entry added at the end of that for $19^{\text {th }}$ April, "In Rome Leo pope and confessor," refers to Pope Leo IX (1048-54). ${ }^{118}$ Leo IX's cult was widely commemorated in Germany and Lotharingia on this date but much less so in northern France. ${ }^{119}$ He is not widely recorded in English liturgical materials, seemingly appearing in no eleventh-century calendars, any other martyrology and only one litany: his name was added later, albeit in a script from the second half of the eleventh century, to that in the Harley 863 psalter copied in Exeter under Bishop Leofric. ${ }^{120}$ Leo IX had particular significance for Exeter and its founding bishop: Leofric sought papal approval for the transfer of the seat of the see from Crediton to Exeter, and a copy of Leo IX's bull was recorded in the sacramentary now known as the Leofric Missal as part of a series of texts on the early history of the see copied at Exeter under Bishop Leofric. ${ }^{121}$ Whilst the calendar in the Leofric Missal was not, however, updated to include Leo IX, it is entirely possible that a different eleventh-century Exeter calendar, now lost, was the source for this entry in Exeter 3518.

\section{The Evidence of South-west Cults}

Exeter 3518 also records a considerable number of south-west cults: at least nine located across Devon and Cornwall, and a further seven from Somerset, Wiltshire and Dorset. There is no theme linking these entries other than geography. By contrast, all the local cults added to Usuard's text in the St Augustine's martyrology explicitly relate to their patron, St Augustine of Canterbury, his companions and successors, and most of those added to the Durham martyrology relate to their patron, St Cuthbert. ${ }^{122}$ This difference is probably in part 
a reflection of this secular cathedral community's own cultic history. Unlike the monastic communities of Durham and St Augustine's whose local liturgical devotions were focussed around their founding bishops, St Cuthbert and St Augustine, and their respective companions and associates, Exeter lacked a single cult or a written tradition upon which it could draw. Instead, Exeter's local liturgical year was focussed around its extensive collection of relics which it commemorated on $22^{\text {nd }}$ May in the words of the entry in Exeter 3518: "In Great Britain in the city of Exeter the translation of the relics of the saints which were translated and are commended for their great and many miracles."123 Exeter tradition from the eleventh century onwards recorded King Æthelstan as having granted one third of his entire relic collection, some 138 items according to the eleventh-century relic lists, together with various grants of property, to the minster church of SS. Peter and Mary in Exeter c. 930, which became the cathedral church in $1050 .{ }^{124}$ Exeter's collection ranged from relics of Christ to those of very local saints. It is not, however, clear whether the feast on $22^{\text {nd }}$ May celebrates the original translation of the relics in 930 or their relocation from the old minster church to the new cathedral building, begun in 1114 and consecrated in $1133 .^{125}$ The importance attached to these relics - as evidenced by the survival of two eleventhcentury lists, one in Latin and one in Old English - perhaps hints at an earlier origin for the feast, but in any case they had achieved a central place in the liturgical year of the Exeter community by the time Exeter 3518 was copied in the 1130 s or 1140 s. The May feast testifies to Exeter's catholic interest in multiple cults in contrast to the rather narrower focus in many English monastic communities at this time.

There is some overlap between the relic lists and the patrons of several local churches mentioned in Exeter 3518. One of these, just outside the east gate of the city, is dedicated to St Sidwell: "The virgin martyr St Sidwell who is found in Britain at the gates of the walls of Exeter" $\left(1^{\text {st }}\right.$ August $) .{ }^{126}$ According to the notice in the eleventh-century Old English relic list, 
she was a virgin martyr killed by her father's hired man. ${ }^{127}$ Her cult is peculiar to Exeter in this period. ${ }^{128}$ She was also linked in the martyrology to the feast commemorating the translation of St Juthwara, referred to there as the "sister of St Sidwell the virgin", to Sherborne on $13^{\text {th }}$ July. ${ }^{129}$ This entry is one of the earliest references to Juthwara's cult; it is not mentioned in any of the surviving eleventh-century English litanies and calendars, although the translation of her cult to Sherborne is mentioned by Goscelin of Saint-Bertin in his late eleventh-century life of Bishop Wulfsige. ${ }^{130}$ It is impossible to know whether knowledge of the Sherborne cult only came to Exeter, therefore, in the twelfth century, but it seems probable in any case that the text was emended at Exeter to include reference to the apparently oral tradition that she was related to Exeter's own virgin saint, Sidwell.

The patrons of various of the major churches from across Exeter's diocese in Devon and Cornwall also feature in Exeter 3518. ${ }^{131}$ Their inclusion might appear natural, testifying to the links which the cathedral clergy wished to make with their wider locality. But in two cases there is evidence to suggest that their presence may also testify to memories from Exeter's pre-Leofrician past. Exeter 3518 mentions the burial of St Rumon the confessor at Tavistock in Great Britain as the last entry on $30^{\text {th }}$ August. ${ }^{132}$ Tavistock was the most significant monastery in Devon, founded sometime in the late tenth century. ${ }^{133}$ Rumon does not feature in any version of the Exeter relic list nor in any of the litanies and calendars surviving from eleventh- and twelfth-century Exeter, nor in other English copies of Usuard. He is mentioned in the early eleventh-century Old English Secgan text. ${ }^{134}$ But Tavistock enjoyed close ties to the bishopric at Crediton under Leofric's predecessor, Lyfing, who held the abbacy of Tavistock until shortly before his death in $1046 .{ }^{135}$ Whoever compiled Exeter 3518 may therefore have drawn on eleventh-century traditions, either written or oral, which predated the moving of the see from Crediton to Exeter. ${ }^{136}$ 
Similarly St Nectan, patron of the minster church of Hartland in north Devon, is not mentioned in any other surviving Exeter material, but was entered into the martyrology for $17^{\text {th }}$ June. ${ }^{137}$ The community was reformed as a house of Augustinian canons under Bishop Bartholomew of Exeter (1161-84); this event seems to have been the stimulus for the composition of various texts. ${ }^{138}$ The twelfth-century canons of Hartland believed that Ethelstan had granted land to the community in the tenth century and that another prominent West Country figure, Gytha, wife of Earl Godwin and mother of King Harold, had given land at Hartland to the community in the eleventh century. ${ }^{139}$ Whilst Gytha is recorded in Domesday Book as owning land there, the other aspects of this story had become muddled by the time the inventio was composed for the canons of Hartland: this records how the body of St Nectan was discovered by the priest of Hartland in the time of King Æthelstan and Bishop Lyfing of Crediton, and that the bishop in recognition of the saint's authority made various gifts to the church at Hartland, including a door to the vestry which was still in use when the text was written. ${ }^{140}$ As noted above, Æthelstan played an important role in Exeter cathedral's foundation myth and it is possible that Exeter's canons, therefore, are the source of this confused chronology.

This review of a sample of the cults added into the main text suggests Exeter 3518 is firmly grounded in late Anglo-Saxon traditions, some dating from Leofric's pontificate, others which appear to predate it, but also with a sprinkling of evidence to suggest more recent influences. However, these additions are not in themselves evidence that Exeter 3518 draws on an eleventh-century martyrological text; whilst some of these entries could have been compiled from oral traditions, others are more likely to have come from now lost calendars. What can be concluded with much more certainty is that the evidence of the over three hundred saints from across the Christian world and Christian history in the litany in the Harley 863 Psalter copied at Exeter under Bishop Leofric testifies to the community's 
scholarly interest in recording saints in the third quarter of the eleventh century; a litany of that length is not very practical. The catholicity of the additional entries included in Exeter 3518 seventy or so years later is testament to the continuing manifestation of that interest in the mid-twelfth century. The degree of independence shown by Exeter 3518 from surviving Canterbury material also suggests that the simple model postulated by Andersen for the promotion of Usuard in England via eleventh-century Canterbury is not sustainable and requires, at the very least, considerably more nuance and allowance for the significance of local forces at work. The evidence considered thus far suggests that the Exeter martyrology is unique amongst the surviving English martyrologies in including such a wide range of cults, both local and national, from the tenth and eleventh centuries. It also suggests that it is feasible that Exeter 3518 could have been based on a late eleventh-century exemplar compiled under either Bishop Leofric or one of his two immediate successors, but the evidence is not conclusive.

\section{The Evidence of the Obits}

The final section of this article briefly considers the evidence of some of the 400 obits recorded in the margins of Exeter 3518 for the light this casts on the composition and history of the martyrology. The majority of entries refer to members of the cathedral community. Many, but not all are dated and some of the dated obits refer to people who had died before the manuscript was written: including "Leofric the first bishop of Exeter, 1072" $\left(11^{\text {th }}\right.$ February), "Brihtric, priest and canon, 1083" (16 $6^{\text {th }}$ February), and "Lanfranc, archbishop of the church of Canterbury" (d. 1089, 26 ${ }^{\text {th }}$ May). ${ }^{141}$ As David Lepine and Nicholas Orme established, the compilers of Exeter 3518 omitted all but two of the seventeen obits added at Exeter into eleventh-century calendar of the Leofric Missal, the service book seemingly in use at Exeter under Bishop Leofric. The only obits to be transferred across into Exeter 3518 are those for Leofric and Brihtric. ${ }^{142}$ For example, an obit for Leofric's predecessor, Bishop 
Lyfing (19 ${ }^{\text {th }}$ March), is recorded in the Leofric Missal calendar but not Exeter $3518 .{ }^{143}$ This process of selection reflects a version of the community's history which began with the cathedral seat's transfer there from Crediton in 1050 rather than one which acknowledged its roots in a different place and earlier times. This is consonant with what else we know of the Exeter community's attitude to their earlier bishops in the twelfth century: later tradition recorded the translation of the bodies of the first two bishops, Leofric and Osbern, at the consecration of the new cathedral in 1133, suggesting they were regarded as its founders by the community. ${ }^{144}$ The decision to include Archbishop Lanfranc but not his successor, Anselm (d. 21 April 1109), perhaps reflects the fact that Bishop William de Warelwast led William Rufus's appeal against Anselm at the papal court in the 1090s. ${ }^{145}$ The hand which entered the obits for Leofric, Brihtric and Lanfranc is very similar, if not identical, to that which wrote the main text, as is that which added the obits for two royal women, Mathilda, wife of Henry I (1 May 1118) and Adela of Blois, mother of Stephen, king of the English (8 March 1137). ${ }^{146}$ The decision to include their names but neither Kings Henry nor Stephen probably reflects particular moments in the community's history rather than a particular affinity between the cathedral community and royal women. The bishop and cathedral supported King Stephen in the civil war, and in his successful siege of Exeter castle in 1136, for example, which may explain why they were anxious to commemorate the death of the queen mother a year later. ${ }^{147}$

But this process of layering, and the recognition that selectivity also underlies the obit entries in the martyrology, provides important background to the marginal notice added next to the entry for $25^{\text {th }}$ September, written in a similar hand to that which wrote the main text: "1066. Harold, son of Earl Godwin, king of the English, having killed Harold, king of the Northmen and all his most victorious army, triumphed in that battle, furthermore, 
Earl Tostig, brother of the aforesaid king of the English was killed by the English with the king of the Northmen."

This reference to the Battle of Stamford Bridge, at which Harold Godwineson defeated and killed his own brother Tostig and Harold Hardrada of Norway, is notably different in its wording to the other obits: the level of detail is more extensive, and the focus is not so much on memorialising the men killed that day but rather on the day's events. It is analogous to an entry from a set of annals, but there are no close parallels for this text in any surviving historical writings. ${ }^{149}$ Although Tostig had a reputation for piety in his lifetime, he had become a political embarrassment by the time his name was copied at Exeter in the midtwelfth century. Why therefore did Exeter's canons choose to retain this notice in their martyrology, when the Durham community deleted the names of Godwin and Tostig from their Liber Vitae, for example? ${ }^{150}$ It is unfortunate that the relevant folio for the battle of Hastings (14 October) is now missing, so we cannot know whether the Exeter community was similarly interested in the deaths of Tostig's brothers, King Harold, Gyrth and Leofwine. There is, however, no obit in Exeter 3518 for their father Godwin (d. 14 April 1053) or mother Gytha, suggesting that the September 25 notice is included more as a matter of historical interest than because of loyalty to this family. ${ }^{151}$ In comparison, the St Augustine's copy of Usuard includes a notice, added in a later twelfth-century hand, linking Harold's death to that of "very many brothers of ours", that is laymen in confraternity with the abbey. ${ }^{152}$ It contains no mention of any other members of Harold's family, suggesting the significance of this notice lay as much with commemorating benefactors in confraternity with the community as with remembrance of key events in national history. The city of Exeter had been a holding of Earl Godwin's family and Gytha, Harold and Tostig's mother, was reportedly in the city when the Conqueror's army arrived to besiege the city in $1067 .{ }^{153}$ It is possible therefore that the inclusion of Tostig's death points to the way in which the 
Exeter community of the twelfth century chose to link their own history to events on the national stage in a similar way to that of St Augustine's.

\section{CONCLUSIONS}

Martyrologies are very tricky texts to work with precisely because they contain the sorts of layering of textual traditions uncovered above. Although none of the textual and manuscript evidence adduced here is decisive in itself, cumulatively it means there is good reason to suspect that Exeter 3518 is based on a copy of the second recension which was already known at Exeter by the late eleventh century. This dating may be refined further to suggest this exemplar was probably brought to Exeter under Bishop Leofric. It was Leofric who introduced the need for a martyrology through the imposition of Chrodegang's Enlarged Rule of Canons on the Exeter community and Leofric's Lotharingian background also explains several of the cults found in Exeter 3518.

There are at least two possibilities as to how this putative exemplar for Exeter 3518 was compiled. The first is that the close parallels with the subjects of the additional entries in CCCC 57 suggest the exemplar for Exeter 3518 was an English manuscript of Usuard written in England before the Conquest. Exeter acquired other service books from Canterbury under Leofric and his successors, and, when coupled with the evidence for the confusion in the entries for the cult of St Eadburh, it is likely that Canterbury was the ultimate source of the martyrology. ${ }^{154}$ This sort of careful reworking of a Canterbury model is closely paralleled in the revisions made to various of the rites in another Exeter manuscript, the pontifical probably written for Bishop Leofric, London, British Library, MS Additional 28188, which Helen Gittos has shown was heavily endebted to earlier Canterbury traditions. ${ }^{155}$ However, given the substantive differences in the wording of the additional entries from all other existing manuscripts, Exeter 3518 is clearly not based on a text closely related to CCCC 57. Rather the variance in wording for the same cults in these and other English manuscripts of 
the period suggests several different copies of Usuard's texts circulated amongst the reform houses of late Anglo-Saxon England. There are precedents for Exeter adapting material from other southern cathedrals: Christopher A. Jones has demonstrated that the Exeter pontifical also included revisions of Aethelwoldian-era Winchester material. ${ }^{156}$ There is therefore every reason to believe that the late eleventh-century community of Exeter might have made similar changes to an Anglo-Saxon copy of Usuard. There is also a second possibility, namely that the compilers of Exeter 3518 drew upon a Canterbury-influenced calendar to revise a copy of Usuard they had acquired independently. Given the nature of the surviving evidence the former is more probable, but both hypotheses are feasible.

Exeter's eleventh-century books are, as Richard Gameson observed, not just the product of a particular moment and reforming impulse, but rather a reflection of the ongoing commitment of Leofric and his two successors to establishing a basic "working" collection for their cathedral's canons. ${ }^{157}$ Leofric's commitment to vernacular texts has understandably attracted considerable interest from Old English scholars and focussed attention on those manuscripts like the tenth-century collection of poetry known as the Exeter Book which make his library exceptional. ${ }^{158}$ But the presence at Exeter in the later eleventh century of Usuard's text, a work which was widely copied in eleventh-and twelfth-century Lotharingia, fits with other indications that many of Exeter's late eleventh-century books were much more conventional and part of the European mainstream of post-Carolingian religious culture and canonical practice.

The Exeter community under its late eleventh-century bishops had a clear interest in collecting information about saints. The relic lists copied in Latin and Old English, the extensive list of saints in the Harley 863 litany and the additions made to Exeter 3518, all testify to a thought-world which valued the cult of saints as a collective endeavour, rather than privileging a particular cult. It has been suggested that there is something rather old 
fashioned about Exeter's catholic interest in saints' relics and collections but it is an approach which they shared with several Lotharingian communities. ${ }^{159}$ Moreover, it can as easily be interpreted as a feature of a community which is part of the same intellectual milieu out of which Archbishop Lanfranc, with his preference for universal rather than local saints, emerged. $^{160}$

Current debates about the attitude of Anglo-Norman churchmen to the Anglo-Saxon cults focus almost exclusively on accounts of particular cults rather than more normative liturgical texts like this martyrology. ${ }^{161}$ If we are really to understand the history of local saints' cults in secular communities such as that in Exeter, which unlike their monastic counterparts did not establish a tradition of narrative history writing, we need to recognise the role played by texts such as this one in constructing and reinforcing the community's knowledge of the saints. Daily readings in chapter over the course of each year reinforced traditions, both oral and written, as much as office lections, building up memories of the patrons of individual churches within its diocese, and at the same time establishing continuity with the tenth-century past of the Anglo-Saxon reformers, and the eleventh-century past of prominent patrons of the community who tied its history to that of the nation and of the universal Church. ${ }^{162}$

This case study has sought to show the value of investigating normative materials. Doing so allows a much more nuanced interpretation of the Anglo-Norman revival of interest in particular local cults. Exeter's reform as a secular community of canons under the Rule of Chrodegang makes it something of a hybrid between the less well-documented secular communities serving many churches in the eleventh century and the reformed monastic communities which often succeeded them. In pointing to the influence of an eleventhcentury Anglo- Latin version of a ninth-century martyrological text on the late eleventhcentury and twelfth-century Exeter cathedral community it suggests there was more textual 
continuity between these two constituencies than has previously been thought. ${ }^{163}$ Recognising the potential of normative texts such as this thus allows us to begin to understand how communities like Exeter which lacked a written historical tradition nevertheless maintained and built their own historical consciousness through the cult of the saints. At the same time it reminds us that the Anglo-Norman churchmen who documented English local cults inherited a very helpful textual legacy from their Anglo-Saxon predecessors.

\section{Appendix}

A Comparison of the Text of a Sample of Entries Between Five of the Earliest English Manuscripts of Usuard and the Text in Exeter 3518.

CCCC 57: Christ Church, Canterbury, s. $\mathrm{x}^{\mathrm{ex}}$ (later added to at Abingdon in s. $\mathrm{xi}^{\text {med }}$ ) $\left(2^{\text {nd }}\right.$ recension); digital images available at Parker Library on the Web https://parker.stanford.edu/parker/actions/page.do?forward=home (last accessed $14^{\text {th }}$ June 2017)

Durham, Cathedral Library, Ms B.iv.24: Christ Church, Canterbury, s. xi ${ }^{\mathrm{ex}}$ (added to at Durham in s. xii $\left.{ }^{\text {in }}\right) ; 1^{\text {st }}$ recension

London, British Library, Ms Cotton Vitellius C. xii: St Augustine's, Canterbury s. xi ${ }^{\text {ex }}$ $\left(2^{\text {nd }}\right.$ recension $)$

London, British Library, Ms Royal 7.E.vi: Christ Church, Canterbury, s. xii $2^{\text {nd }}$ recension)

Exeter, Cathedral Library, Ms 3518: Exeter, s. xii ${ }^{\text {med }}$ ( ${ }^{\text {nd }}$ recension)

Oxford, Bodleian Library, Ms Rawlinson D 1225: prov. St Chad's, Shrewsbury, s.xii $\left(2^{\text {nd }}\right.$ recension $)$ 
1) 28 February: Oswald, archbishop of York

CCCC 57, fol. 49r: "Ipso die depositio sancti oswaldi archiepiscopi."

Durham, Cathedral Library, Ms B.IV.24: No entry for Archbishop Oswald.

London, British Library, Ms Cotton Vitellius, C. xii: no entry.

London, British Library, Ms Royal 27 E.vi: no entry.

Exeter Ms 3518, fol. 5r: "Item in britannia maiori apud Wircestram sancti oswaldi archiepiscopi et confessoris."

Oxford, Bodleian Library, Ms Rawlinson D 1225, fol. 35r (added in s. xii hand in the margin): "In britannia ciuitate uigornia depositio sancti osuualdi eboracensis archiepiscopi."

2) 19 April: Aelfheah

CCCC 57, fol. 55r (added in later s. xi hand above the line): "Eodem die passio sancti aelfegi archiepiscopi et martyris."

Durham, MS B.IV.24, fol. 20v: "Eodem die passio sancti elfeagi archiepiscopi."

Exeter Ms 3518, fol. 13v: "In brittannia maiori apud cantuarbiram sancti aelfegi archiepiscopi et martyris."

London, British Library, Ms Cotton Vitellius, C. xii: no entry.

London, British Library, Ms Royal 7 E.vi, fols. 21v-22r: "Eodem die SANCTI ÆLFEGI cantuariensis archiepiscopi qui ab exercitu paganorum post dirutam illius urbem post cruentam innocentis populi cedem post te(m)pli expoliationem uinctus abductus est et per septem menses uariis tormentorum suppliciis cruciatus tandem furentium manibus paganorum lapidatus."

Oxford, Bodleian Library, Ms Rawlinson D 1225: no entry.

3) 19 May: Dunstan 
CCCC 57, fol. 60r (added in later s. xi hand above the line): "Eodem die deposiuit sanctus dunstanus archiepiscopus in christo".

Durham, Ms B.IV.24, fol. 23r: "Ipso die depositio sancti dunstani archiepiscopi cantuariae ubi etiam sepultus usque hodie crebris refulgent miraculis."

London, British Library, Ms Cotton Vitellius, C. xii, fol. 130r: "Eodem die depositio sancti beati dunstani archiepiscopi et confessoris."

London, British Library, Ms Royal 7 E.vi, fol. 28v: "In ciuitate dorobernia natale sancti patris nostri DUNSTANI archiepiscopi qui ab ipso matris utero sanctificatus omne tempus uitae suae magnifice duxit unde et glorioso fine quieuit."

Exeter, Ms 3518, fol. 22r: "In brittannia maiori ciuitate cantuarbiria sancti dunstani archiepiscopi et confessoris."

Oxford, Bodleian Library, Ms Rawlinson D 1225: no entry.

4) 31 August: Aidan, bishop of Lindisfarne and Cuthburh, abbess of Wimborne

CCCC 57, fol. 76r: "Eodem die sancti aedani episcopi cuius animam sanctus cuthberhtus in caelum ab angelis ferri uidit. Eodem die sanctae cuthburge uirginis.”

Durham, Ms B.iv.24, fol. 31r (added early s. xii hand in right hand margin): "In britannia sancti aidani primi lindisfarnensis episcopi. Eodem die commemoration sanctarum reliquiarum eiusdem ecclesiae". No entry for Cuthburh.

Exeter, Ms 3518, fol. 47r: "In brittannia maiori apud durelmam depositio sancti aidani episcopi et confessoris cuius relique sunt repositae in ecclesia sancti cuthberti. Ipso die sanctae cuthburgae uirginis."

London, British Library, Ms Cotton Vitellius, C. xii, fol. 139r: "In britannia depositio sancti aidani episcopi et confessoris. Eodem die natale sanctae cuthbergis uirginis." London, British Library, Ms Royal 7 E.vi, fol. 49v: "Eodem die sancti aidani episcopi (cuiusstruckthrough)"(last line on page; end of entry with obits erased at top of fol. 50r). 
Oxford, Bodleian Library, Ms Rawlinson D 1225: no entry.

\section{$\underline{\text { Acknowledgements }}$}

The research for this paper was conducted with the support of the Humanities in the European Research Area funded project, After Empire: Using and not using the Past in the Crisis of the Carolingian World, c.900-c.1050 (UNUP), funded from the European Union's Research and Innovation Horizon 2020 programme under grant agreement no. 649387. I began research whilst part of the European Research Council-funded The Past in its Place project (2012-6; grant agreement no. 284085). I should like to thank my fellow team members and the anonymous reviewers for this journal for their generous and careful criticisms.

\footnotetext{
1 "Rumonus ibi sanctus predicatur et iacet episcopus, pulchritudine decoratus scrinii, ubi nulla scriptorum fides assistit opinioni. Quod non solum ibi sed in multis locis Angliae inuenies, uiolentia (credo) hostilitatis abolitam omnem gestorum notitiam, nuda tantum sanctorum nomina et si quae modo pretendunt miracula tantum sciri." William of Malmesbury, Gesta Pontificum Anglorum, 2.95, ed. and trans. M. Winterbottom with R. M. Thomson, 2 vols (Oxford, 2007), 1: 316. This passage is well-known: James Campbell, "Some Twelfth-Century Views of the Anglo-Saxon Past," in his Essays in Anglo-Saxon History (London, 1986), 209-228 at 218; John Blair, “A Saint for Every Minster? Local Cults in Anglo-Saxon England," in Local Saints and Local Churches in the Early Medieval West, eds Alan Thacker and Richard Sharpe (Oxford, 2002), 455-94 at 455; Paul Antony Hayward, "Saints and Cults," in A Social History of England 900-1200, eds Julia Crick and Elisabeth van Houts (Cambridge, 2011), 309-20 at 319; and Robert Bartlett, "The Viking Hiatus in the Cult of Saints as Seen in the Twelfth Century," in The Long Twelfth-century
} 
View of the Anglo-Saxon Past, eds Martin Brett and David A. Woodman (Aldershot, 2015), $13-26$ at 16.

${ }^{2}$ Bartlett, "The Viking Hiatus"; Julia Barrow, "Danish Ferocity and Abandoned Monasteries: The Twelfth-century View," in The Long Twelfth-century View, eds Brett and Woodman, 7793, especially discussion of European use of this trope at 92; Anna Trumbore-Jones, "Pitying the Desolation of Such a Place: Rebuilding Religious Houses and Constructing Memory in the Wake of the Viking Invasions," Viator: Medieval and Renaissance Studies 37 (2006): 85102. This trope is part of wider developments in historical memory at this time, that is "the new past forged in the eleventh century" by writers across continental Europe, "with its emphasis on radical discontinuity" and based on "the image of destruction, disintegration and confusion in the tenth century”, which Patrick J. Geary identified: Phantoms of Remembrance. Memory and Oblivion at the End of the First Millenium (Princeton, NJ, 1994), 23.

${ }^{3}$ For the dependence on oral traditions elsewhere see Julia M.H. Smith, "Oral and Written: Saints, Relics and Miracles in Brittany, c. 850-1250," Speculum 65 (1990): 309-43. ${ }^{4}$ Anglo-Saxon Litanies of the Saints, ed. Michael Lapidge, Henry Bradshaw Society (hereinafter HBS) 106 (London, 1991); English Monastic Litanies of the Saints after 1100, 2 vols, ed. Nigel J. Morgan, HBS 119-120 (London, 2012-13); England Kalendars before A.D.1100, ed. Francis Wormald, Henry Bradshaw Society 72 (London, 1934); Rebecca Rushforth, Saints in English Kalendars before A.D.1100, Henry Bradshaw Society 117 (London, 2008). For relic lists see the Exeter relic list edited by Patrick W. Conner in his Anglo-Saxon Exeter: A Tenth-century Cultural History, Appendix II (Woodbridge, 1993), 171-209; for the Waltham Abbey relic list see the edition by Paul G. Schmidt in his "König Harold und die Reliquien von Waltham Abbey, Essex: Die Reliquienliste in B.L.Harley 
3776," in Festschrift für Hans Schabram zu 65. Geburtstag, ed. K.R.Grinda and C.-D.Wetzel (Munich, 1993), 75-90 and N. Rogers, "The Waltham Abbey Relic-list," in England in the Eleventh Century: Proceedings of the 1990 Harlaxton Symposium, ed. Carola Hicks (Stamford, 1992), 157-181.

${ }^{5}$ Susan Boynton, Shaping a Monastic Identity. Liturgy and History at the Imperial Abbey of Farfa, 1000-1125 (Ithaca, NY, 2006); Margot E. Fassler, The Virgin of Chartres. Making History through Liturgy and the Arts (New Haven, CT, 2010).

${ }^{6}$ Medieval Cantors and Their Craft: Music, Liturgy and the Shaping of History, 800-1500, eds Katie Ann-Marie Bugyis, A.-R. Kraebel and Margot E. Fassler (Woodbridge ,2017). ${ }^{7}$ Fassler acknowledges the importance of the surviving martyrology/necrology for the history of eleventh-century Chartres but does not investigate it in any detail: The Virgin of Chartres, 96-97.

${ }^{8}$ Michael Lapidge and Rosalind C. Love, “The Latin Hagiography of England and Wales (600-1550)," in Hagiographies. Histoire international de la literature hagiographique latine et vernaculaire en Occident des origins à 1550, ed. Guy Philippart, 6 vols (Turnhout, 19942010), 3: 203-325. David Rollason, Saints and Relics in Anglo-Saxon England (Oxford, 1989). The first phase of Anglo-Saxon hagiographical writing took place in the seventh and early eighth centuries.

${ }^{9}$ Campbell, “Some Twelfth-Century Views,” 218-9; Blair, “A Saint for Every Minster?,” 459. For evidence of the participation of late Anglo-Saxon female religious houses in this revival see the works by Stephanie Hollis: "St Edith and the Wilton Community" and "Wilton as a Centre of Learning," in Writing the Wilton Women: Goscelin's 'Legend of Edith' and 'Liber Confortarius', eds W.R. Barnes and Stephanie Hollis (Turnhout, 2005), 245-80, 307-40; "Barking's Monastic School, Late Seventh to Twelfth Century: History, 
Saint-Making and Literary Culture," in Barking Abbey and Its Anglo-Saxon Context, eds Jennifer N. Brown and Donna Alfano Bussell (Woodbridge, 2012), 33-55, at 40-53; "The Literary Culture of the Anglo-Saxon Royal Nunneries: Romsey and London, British Library, MS Lansdowne 436," in Nuns' Literacies in Medieval Europe: The Hull Dialogue, eds Virginia Blanton, Veronica O’Mara and Patricia Stoop (Turnhout, 2013), 169-183. For Goscelin of Saint-Bertin's debt to written as well as oral traditions at Wilton see Katie AnnMarie Bugyis, "Recovering the Histories of Women Religious in England in the Central Middle Ages: Wilton Abbey and Goscelin of Saint-Bertin," Journal of Medieval History 42 (2016): 285-303.

${ }^{10}$ D. W. Rollason, “Lists Of Saints’ Resting Places in Anglo-Saxon England,” Anglo-Saxon England 7 (1978): 61-93; Max Förster, Zur Geschichte des Reliquienkultus in Altengland (Munich, 1943).

${ }^{11}$ Campbell, "Some Twelfth-Century Views," 219.

${ }^{12}$ David Knowles, The Monastic Order in England (Cambridge, 1940), 118; R. W. Southern, "Aspects of the European Tradition in Historical Writing IV: The Senses of the Past," Transactions of the Royal Historical Society, series 5, 23 (1973): 243-63.

${ }^{13}$ S. J. Ridyard, “Condigna Veneratio. Norman Attitudes to Anglo-Saxon Saints,” AngloNorman Studies 9 (1987): 179-206.

${ }^{14}$ Three Eleventh-century Anglo-Latin Lives: Vita S. Birini, Vita et Miracula S. Kenelmi and Vita S. Rumwoldi, ed. and trans. Rosalind C. Love (Oxford, 1996), xxxiii-xxxix.

${ }^{15}$ Jay Rubenstein, "Liturgy Against History: The Competing Visions Of Eadmer and Lanfranc of Canterbury,” Speculum 47 (1999): 279-309; Paul Antony Hayward, “Translationnarratives in Post-Conquest Hagiography and English Resistance to the Norman Conquest," 
Anglo-Norman Studies 21 (1998): 67-93; idem, "Saints and Cults"; Tom Licence, "The Cult of St Edmund," in Bury St Edmunds and the Norman Conquest, ed. Tom Licence (Woodbridge, 2014), 104-30; Rebecca Browett, “The Fate of Anglo-Saxon Saints,” History 101 (2016): 183-200.

${ }^{16}$ For a case study of the different sorts of materials which survive for one cult see Michael Lapidge with contributions by John Crook, Robert Deshman and Susan Rankin, The Cult of St Swithun, Winchester Studies 4.2 (Oxford, 2003).

${ }^{17}$ See n. 4 above.

${ }^{18}$ Rubenstein, "Liturgy against History”. He cites T. A. Heslop, “The Canterbury Calendars and the Norman Conquest," in Canterbury and the Norman Conquest, eds Richard Eales and Richard Sharpe (London, 1995), 53-86, contra Richard Pfaff, "Lanfranc's Supposed Purge of the Anglo-Saxon Calendar," in Warriors and Churchmen in the High Middle Ages: Essays Presented to Karl Leyser, ed. Timothy Reuter (London, 2002), 95-108.

${ }^{19}$ Benjamin Pohl, “The 'Bec Liber Vitae': Robert of Torigni's Sources for Writing the History of the Clare Family at Le Bec, c. 1128-54," Revue Bénédictine 126 (2016): 324-72. 20 "Historical Martyrologies in the Benedictine Cultural Tradition," in Benedictine Culture, 750-1050, eds W. Lourdaux and D. Verhelst (Leuven, 1983), 114-31. See also the more recent comments by Felice Lifshitz, The Name of the Saint: The Martyrology of Jerome and Access to the Sacred in Francia, 627-827 (Notre Dame, Indiana, 2006), 3: "Both martyrologies and calendars have been virtually ignored by non-liturgists, despite the importance of such documents to medieval life and the insights into that life which their exploration can be made to yield." The earliest, "Hieronymian" martyrologies, seemingly compiled in the fifth or sixth centuries, contained entries for days of the year listing the name and place of burial of the saints remembered on that day; historical martyrologies, a 
seemingly eighth-century development, retain this format but incorporate a brief history of the saint into the entry: Jacques Dubois, Les Martyrologes du moyen âge latin, Typologie des sources du moyen âge occidental 26 (Turnhout, 1978).

${ }^{21}$ Memoriale Qualiter, c. 2, ed. D. C. Morgand and Synodi Secundae Aquisgranensis Decreta Authentica (817), c. 36, ed. Josef Semmler in Initia Consuetudinis Benedictinae:

Consuetudines Saeculi Octavi et Noni, Corpus Consuetudinum Monasticarum 1, ed. Kassius Hallinger (Siegburg, 1963), 235, 480. For wider discussion of books used in monastic chapter see Teresa Webber, "Monastic Space and the Use of Books in the Anglo-Norman Period," Anglo-Norman Studies 36: Proceedings of the Battle Conference 2013, ed. David Bates (Woodbridge, 2014), 221-40 at 231-34. See also n. 69 below.

${ }^{22}$ Lifshitz, The Name of the Saint, 129: "The ultimate triumph of the narrative martyrology as an instrument of daily recitation was a function not only of narrativity but also of historicity."; Rosamond McKitterick, Perceptions of the Past in the Early Middle Ages (Notre Dame, Indiana, 2006), 52-4; Alan Thacker, "Bede and His Martyrology," in Listen, O Isles, Unto Me: Studies in Medieval Word and Image in Honour of Jennifer O'Reilly, eds Elizabeth Mullins and Diarmuid Scully (Cork, 2010), 126-141.

${ }^{23}$ The Old English Martyrology. Edition, Translation and Commentary, Christine Rauer (Cambridge, 2013); Christine Rauer, The Old English Martyrology: An Annotated Bibliography, available at https://www.st-andrews.ac.uk/ cr30/martyrology/ (accessed $31^{\text {st }}$ March 2017).

${ }^{24}$ Eef Overgaauw has identified some fifty eleventh-and twelfth-century versions of the first recension of Usuard's martyrology in the dioceses of Utrecht and Liège: Les Martyrologes manuscrits des anciens dioceses d'Utrecht et de Liège (Hilversum, 1993). On its popularity in England see discussion below. 
${ }^{25}$ Mechthild Gretsch, "Cambridge, Corpus Christi College 57: A Witness to the Early Stages of the Benedictine Reform in England?," Anglo-Saxon England 32 (2003): 111-46. On this manuscript see also Timothy Graham, "Cambridge, Corpus Christi College 57 and Its AngloSaxon Users," in Anglo-Saxon Manuscripts and their Heritage, eds Phillip Pulsiano and Elaine M. Treharne (Aldershot, 1998), 21-69; Helmut Gneuss and Michael Lapidge, AngloSaxon Manuscripts. A Bibliographical Handlist of Manuscripts and Manuscript Fragments Written or Owned in England up to 1100 (Toronto, 2014), no. 41, 51-52. A digital copy of this manuscript is available at the Parker Library on the Web, https://parker.stanford.edu (accessed 22 $2^{\text {nd }}$ June 2017).

${ }^{26}$ Jan Gerchow, Die Gedenküberlieferung der Angelsachsen. Mit einem Katalog der libri vitae und Necrologien (Berlin and New York, 1988), 233-52

${ }^{27}$ For an overview see Dubois, Les Martyrologes. On the methodological challenges inherent in the study of martyrologies the work of Henri Quentin also remains fundamental: Le Martyrologe historique du moyen âge. Étude sur la formation du martyrologe romain (Paris, 1908).

${ }^{28}$ The authorial copy of Usuard is known as the second recension: Paris, Bibliothèque nationale de France, Ms lat. 13745, a digital facsimile of which is available at Gallica: http://gallica.bnf.fr (accessed $31^{\text {st }}$ March 2017); it is edited in Le Martyrologe d'Usuard. Texte et commentaire, ed. Jacques Dubois, Subsidia hagiographica 40 (Brussels, 1965). Usuard's text has not been much studied by Carolingianists with the exception of the brief comments by J. M. Wallace-Hadrill in The Frankish Church (Oxford, 1983), 355, and the article by Janet L. Nelson, “The Franks, the Martyrology of Usuard and the Martyrs of Cordoba," in Martyrs and Martyrologies, Studies in Church History 30, ed. Diana Wood (Oxford, 1993), 67-80. 
${ }^{29}$ Frank Barlow, "Leofric and His Times," in Leofric of Exeter. Essays in Commemoration of the Foundation of Exeter Cathedral Library in A.D.1072, ed. Frank Barlow (Exeter, 1972), 116; Christopher J. Holdsworth, "From 1050 to 1307," in Unity and Variety. A History of the Church in Devon and Cornwall, ed. Nicholas Orme (Exeter, 1991), 23-52.

${ }^{30}$ Elaine Drage, "Bishop Leofric and the Exeter Cathedral Chapter (1052-1072): A Reassessment of the Manuscript Evidence” (University of Oxford, D.Phil. thesis, 1978); Joyce Hill, "Leofric of Exeter and the Practical Politics of Book Collecting," in Imagining the Book, eds Stephen Kelly and John J. Thompson, (Turnhout, 2006), 77-97; Elaine Treharne, "Producing a Library in Late Anglo-Saxon England," The Review of English Studies 54 (2003): 155-172; eadem, “The Bishop's Book: Leofric's Homiliary and EleventhCentury Exeter," in Early Medieval Studies in Memory of Patrick Wormald, eds Stephen Baxter, Catherine Karkov, Janet L.Nelson and David Pelteret (Farnham, 2009), 521-37; Richard Gameson, "The Origin of the Exeter Book of Old English Poetry,” Anglo-Saxon England 25 (1996): 135-85; idem, "Manuscrits normands à Exeter aux XIe et XIIe siècles," in Manuscrits et enluminures dans le monde normand (Xe-XVe siècles): Colloque de Cerisyla-Salle (Octobre, 1995), eds Pierre Bouet and Monique Dosdat (Caen, 1999), 107-128; R.M. Thomson, Books and Learning in Twelfth-century England: The Ending of 'Alter Orbis'. The Lyell Lectures 2000-2001 (Walkern, Herts, 2006), 50-51, 58-9, 101-4; Jesse D. Billett, “The Divine Office and the Secular Clergy in Later Anglo-Saxon England," in England and the Continent in the Tenth Century. Studies in Honour of Wilhelm Levison (1876-1947), eds David Rollason, Conrad Leyser and Hannah Williams (Turnhout, 2010), 429-471For a slightly earlier period see Peter Stokes, English Vernacular Minuscule from Athelred to Cnut, circa 990-circa 1035 (Cambridge, 2014).

${ }^{31}$ Gameson, "Manuscrits normands"; Thomson, Books and Learning. 
${ }^{32}$ Billett, "The Divine Office,"436-440.

${ }^{33}$ For a full description see Neil R. Ker, Medieval Manuscripts in British Libraries, 5 vols (Oxford, 1969-2002), 2: 828. J.N. Dalton asserted that the boards are fourteenth-century, without giving his reasons: see the description in Ordinale Exon. (Exeter Chapter Ms 3502 Collated with Parker Ms 93), ed. J. N. Dalton, 2 vols, Henry Bradshaw Society (London, 1909), 1: xxv.

${ }^{34}$ All dates which are given in all copies of Usuard according to the Roman calendar have been adapted to those of the Gregorian calendar.

${ }^{35}$ Julia Crick, personal communication; I am extremely grateful to her for looking at this manuscript with me and also to Francisco Alvarez-Lopez for pointing out the salmon pink and blue used for the initials are a feature of other twelfth-century Exeter manuscripts. Ker, Medieval Manuscripts, 2: 828, dates Exeter 3518 s. xii ${ }^{1}$ but Richard Gameson did not include it in his study of pre-1125 manuscripts at Exeter: "Manuscrits normands".

${ }^{36}$ Unfortunately the text of these entries is no longer legible. For the possibility that such erasures may result from sentences of excommunication see Sarah Hamilton, "Medieval Cursing and Its Uses," Haskins Society Journal (forthcoming).

${ }^{37}$ See historical texts and obituary for Leofric added at Exeter in $\mathrm{s} . \mathrm{xi}^{2}$ to a sacramentary which was seemingly at Canterbury in the tenth century: The Leofric Missal, ed. Nicholas Orchard, 2 vols, Henry Bradshaw Society 113-4 (London, 2002), 2: 2-6.

38 “Lefricus, apud Lotharingos altus et doctus...”: William of Malmesbury, Gesta Pontificum Anglorum, 2. 94. 4-5, at 1:314.

39 "Hic Lefricus ... episcopatum et canonicos statuit, qui contra morem Anglorum ad formam Lotharingorum uno triclinio comederent, uno cubiculo cuitarent.”, ibid., 1: 314. On the Rule of Chrodegang see Jerome Bertram, The Chrodegang Rules. The Rules for the Common Life 
of the Secular Clergy from the Eighth and Ninth Centuries. Critical Texts with Translations and Commentary (Aldershot, 2005); for the Rule of Chrodegang in this period, with some important criticisms of Bertram, see J. Barrow, "Review Article: Chrodegang, His Rule and Its Successors," Early Medieval Europe 14 (2006): 201-12. A bilingual-version of the Rule was copied for Leofric: The Old English Version of the Enlarged Rule of Chrodegang: Edited Together with the Latin and an English Translation, ed. Brigitte Langefeld (Frankfurt am Main, 2003); on which see n. 70 below.

${ }^{40}$ His inventory, in Latin and Old English, survives in two manuscripts from Exeter and is edited in Conner, Anglo-Saxon Exeter, 226-235.

${ }^{41}$ See n. 30 above.

${ }^{42}$ Ordinale Exon, ed. J. N. Dalton, G.H. Doble, 4 vols, Henry Bradshaw Society 37-8, 43, 79 (London, 1909-1940), 2: 371-459.

${ }^{43}$ Ordinale Exon, ed. Dalton et al, 4: 1-105.

${ }^{44}$ E.g. Lynette Olson, Early Monasteries in Cornwall (Woodbridge, 1989); O. J. Padel, "Local Saints and Place-Names in Cornwall," in Local Saints, eds Thacker and Sharpe, 303360; Nicholas Orme, The Saints of Cornwall (Oxford, 2000).

${ }^{45}$ David Lepine and Nicholas Orme, Death and Memory in Medieval Exeter, Devon and Cornwall Record Society, New Series 46 (Exeter, 2003), 251-58; Robert Bartlett, Why Can the Dead Do Such Great Things? Saints and Worshippers from the Martyrs to the Reformation (Princeton and Oxford, 2013), 131.

${ }^{46}$ For an account of all the recensions and an edition of this text see Jacques Dubois, Le Martyrologe d'Usuard. Texte et commentaire, Subsidia hagiographica 40 (Brussels, 1965), supplemented by his subsequent establishment of a third, primitive, recension: Jacques 
Dubois, “À la recherché de l'état primitif du martyrologe d’Usuard: le manuscrit de Fécamp," Analecta Bollandiana 95 (1977): 43-72.

${ }^{47}$ Dubois suggests Usuard composed his text across the years c. 850 until his death $c .877:$ Le Martyrologe d'Usuard, 134-139. On the popularity of his text see below.

${ }^{48}$ Dubois, “À la recherché de l'état primitif,”; Eef A.Overgaauw, "Les deux recensions de la lettre-préface d'Usuard à Charles le Chauve et les trois recensions de son martyrologe," Bulletin du Cange 48-9 (1990): 85-101 at 93-95.

${ }^{49}$ Dubois, Le Martyrologe d'Usuard, 134-37. In addition to works cited below see Jean-Loup Lemaître, “L'édition du martyrologe d'Usuard publiées à Cologne en 1515 et en 1521 par Johann Landen," Analecta Bollandiana 131 (2013): 375-402. For a case study of its popularity see Eef A. Overgaauw, Les Martyrologes manuscrits des anciens dioceses d'Utrecht et de Liège (Hilversum, 1993).

${ }^{50}$ The letter-preface survives in two versions; Overgaauw shows how what was identified by Henri Quentin as a later version is in fact the original text as it accompanies six manuscripts of the "primitive recension': "Les deux recensions".

${ }^{51}$ Cf. Augustine, Contra Faustum Manichaeum, XX.21, PL 42, 384-5. For editions of all three prefaces see Dubois, Martyrologe d'Usuard, 144-46.

${ }^{52}$ Dubois, Martyrologe d'Usuard, 13-37; M. G. Andersen, “The Second Recension of the Martyrology of Usuardus,” Revue Bénédictine 121 (2011): 382-92.

${ }^{53}$ Graham, "Cambridge, Corpus Christi College 57," in Anglo-Saxon Manuscripts, eds Pulsiano and Treharne, 21-69; Gretsch, "Cambridge, Corpus Christi College 57”.

${ }^{54}$ On the obits see Jan Gerchow, Die Gedenküberlieferung der Angelsachsen. Mit einem Katalog der libri vitae und Necrologien (Berlin and New York, 1988), 233-52. For the 
attribution to late tenth-century Christ Church, Canterbury see Gameson, "The Origins of the Exeter Book," 175-76, on the grounds of its relationship to texts in other Canterbury early eleventh-century manuscripts as well as its script, contra Gretsch who suggests it may have been made either at Canterbury or Abingdon: "Cambridge, Corpus Christi College 57," 113. Note the caveat of David Ganz that it is often impossible to date and localise Square Minuscule hands, such as that found in CCCC 57, on solely palaeographical grounds: "Latin Script in England c. 900-1100 a) Square Minuscule," in The Cambridge History of the Book Volume 1: c. 400-1100, ed. Richard Gameson (Cambridge, 2012), 188-96.

${ }^{55}$ David N. Dumville, "St Patrick in an Anglo-Saxon Martyrology," in Saint Patrick A.D.493-1993, ed. David N. Dumville (Woodbridge, 1993), 243-4; Gretsch, “Cambridge, Corpus Christi College 57," 135-6.

${ }^{56}$ On which see the contributions in St Dunstan: His Life, Times and Cult, eds Nigel Ramsay, Margaret Sparks and Tim Tatton-Brown (Woodbridge, 1992).

${ }^{57}$ Andersen, "The Second Recension," 384-5.

${ }^{58}$ Ibid.; Gneuss, "Liturgical Books," 128. On the attribution of the scribe of the martyrology in Durham B.IV.24 to the cantor and historian Symeon of Durham see Michael Gullick, "The Scribes of the Durham Cantor's Book (Durham, Dean and Cathedral Library, MS B. IV. 24) and the Durham Martyrology Scribe," in Anglo-Norman Durham 1093-1193, eds David Rollason, Margaret Harvey and Michael Prestwich (Woodbridge, 1994), 93-110; idem, "The Hand of Symeon of Durham: Further Observations on the Durham Martyrology Scribe," in Symeon of Durham. Historian of Durham and the North, ed. David Rollason (Stamford, 1998), 14-31.

${ }^{59}$ Andersen, "The Second Recension"; to her list should be added the fragment written in an English, Norman or French s. xii ${ }^{1}$ hand, now Canterbury, Cathedral Library, Ms Add. 127/20: 
Richard Gameson, The Earliest Books of Canterbury Cathedral. Manuscripts and Fragments to c. 1200 (London, 2008), 221-25.

${ }^{60}$ Michael Lapidge, The Cult of St Swithun, 30: "No doubt many monastic foundations had similarly annotated copies of Usuard in the later Anglo-Saxon period."

${ }^{61}$ Andersen, "The Second Recension," 388.

${ }^{62}$ Symeon of Durham: Historian Of Durham and the North, ed. David W. Rollason (Stamford, 1998).

${ }^{63}$ F. Barlow, "William of St Calais," Oxford Dictionary of National Biography (Oxford, 2004-2016), at www.oxforddnb.com (last accessed $21^{\text {st }}$ March 2017).

${ }^{64}$ Thomson, Books and Learning, 59.

${ }^{65}$ London, British Library, Ms Cotton Vitellius C.xii, fols. 114-57. On the cult of St Augustine at St Augustine's see Richard Sharpe, “The Setting of St Augustine's Translation, 1091," Canterbury and the Norman Conquest: Churches, Saints and Scholars, 1066-1109, eds Richard Eales and Richard Sharpe (London, 1995), 1-13; on Lanfranc's relations with St Augustine's see H.E.J. Cowdrey, Lanfranc. Scholar, Monk, and Archbishop (Oxford, 2003), $167-72$.

${ }^{66}$ N. R. Ker, Catalogue of Manuscripts Containing Anglo-Saxon (Oxford, 1957), no. 50, 9091; Gneuss and Lapidge, Anglo-Saxon Manuscripts, no. 66, 88.

${ }^{67}$ The digital images are available at the Parker Library On the Web: https://parker.stanford.edu/ (last accessed $21^{\text {st }}$ March 2017).

${ }^{68}$ Conner, Anglo-Saxon Exeter, 232.

${ }^{69}$ Baudoin de Gaiffier, "De l'usage et de la lecture du martyrologe: témoignages antérieurs au XIe siècle,” Analecta Bollandiana 78 (1960): 40-59. 
${ }^{70}$ N. R. Ker, Catalogue of Manuscripts Containing Anglo-Saxon (Oxford, 1957), nos 46-7, 74-6; The Old English Version of the Enlarged Rule of Chrodegang, ed. Langefeld.

${ }^{71}$ Ker, Catalogue of Manuscripts Containing Anglo-Saxon, nos 47 and 50, 76-91.

${ }^{72}$ Michael Lapidge, "Surviving Booklists from Anglo-Saxon England,” in Learning and Literature in Anglo-Saxon England: Studies Presented to Peter Clemoes on the Occasion of His Sixty-Fifth Birthday, eds Michael Lapidge and Helmut Gneuss (Cambridge, 1985), 33-89 at 67; Gameson, "The Origins of the Exeter Book," 141; Christine Rauer, The Old English Martyrology. Edition, Translation and Commentary (Cambridge, 2013), 20-21; Gneuss and Lapidge, Anglo-Saxon Manuscripts, nos 60 and 66, 75, 88; Elaine Treharne's description of CCCC 196 for The Production and Use of English Manuscripts 1060 to 1220 at http://www.le.ac.uk/english/em1060to1220/ (last accessed 20 ${ }^{\text {th }}$ March 2017).

${ }^{73}$ Helmut Gneuss, "Liturgical Books in Anglo-Saxon England and Their Old English Terminology," in Learning and Literature, ed. Lapidge and Gneuss, 91-141 at 128-9.

${ }^{74}$ Conner, Anglo-Saxon Exeter, 232.

75 "Et post lectionem recitetur, etas mensis et lune, et nomina sanctorum quorum festa crastinus excipiet dies": The Old English Version of the Enlarged Rule of Chrodegang, ed. Langefeld, c. 16, 206. Cf. the practice enjoined by the Aachen legislation which makes the use of the martyrology clearer: "Ut ad capitulum primitus martryologium legatur et dicatur uersus, deinde regula aut omelia quaelibet legatur.", Synodi Secundae Aquigranensis Decreta Authentica (817), c. 36, ed. Semmler, in Corpus Consuetudinum Monasticarum 1, ed. Hallinger, 480.

${ }^{76}$ Rauer, The Old English Martyrology, 17. She refines here the position she took in 2007 when, having argued for the hybrid nature of the text, she suggested that the reading of 
Usuard's text "is more likely to have been the norm" in the chapter of later Benedictine houses although the "secular clerics of later Anglo-Saxon England, specifically of Exeter and Glastonbury, may indeed have used the Old English Martyrology for a similar kind of ceremonial purpose, as well as for field-trip preaching": eadem, "Usage of the Old English Martyrology," in Foundations of Learning. The Transfer of Encyclopaedic Knowledge in the Early Middle Ages, eds R. H. Bremmer Jr and K. Dekker (Paris, 2007), 125-146 at 144.

${ }^{77}$ Cambridge, Corpus Christi College, Ms 41, pp. 122-32 on which see Ker, Catalogue of Manuscripts Containing Anglo-Saxon, no. 32; Rauer, The Old English Martyrology, 21-22. See Jesse Billett's forthcoming Henry Bradshaw Society edition of the marginalia in CCCC 41.

${ }^{78}$ G. Oliver, Lives of the Bishops of Exeter and a History of the Cathedral (Exeter, 1861), 304.

${ }^{79}$ CCCC 196 measures 285 x 170mm, Exeter 3518 measures 220x162 mm, although its margins have been cropped by a later binder it is therefore improbable that they were bound together in the fourteenth century.

${ }^{80}$ Frank Barlow, "William de Warelwast (d. 1137)," Oxford Dictionary of National Biography; D. W. Blake, "Bishop William Warelwast," The Devonshire Association for the Advancement of Science, Literature and Art. Report and Transactions 104 (1972): 15-33; idem, "The Bishops of Exeter 1138-1160," The Devonshire Association for the Advancement of Science, Literature and Art. Report and Transactions 114 (1982): 71-78 at 71-74.

${ }^{81}$ Oliver, Lives, 305; Richard W. Pfaff, The Liturgy in Medieval England: A History (Cambridge, 2009), 389-90. 
${ }^{82}$ Stephen Marritt, "Bishop William de Warelwast and the Churches and Saints of Devon and Cornwall" (unpublished paper). I should like to thank Dr Marritt for sending me a copy of his work.

${ }^{83}$ Rushforth, Saints in English Kalendars, Table VIII.

${ }^{84}$ Rushforth, Saints in English Kalendars,Table VIII.

${ }^{85}$ London, British Library, Ms Cotton Vitellius A. xviii; Rushforth, Saints in English Kalendars, Tables II and IX.

${ }^{86}$ Simon Keynes, “Giso, Bishop of Wells (1061-88),” Anglo-Norman Studies 19 (1997): 203271, who describes the calendar in Giso's sacrementary as “reek(ing) of nothing more distinctive than the inter-connected world of the eleventh-century English church" as well as including "several unusual feasts likely to be of interest to a man from Lorraine" at 253.

${ }^{87}$ Exeter 3518, fols. 5r (Oswald of Worcester), 13v (Ælfheah), 22r (Dunstan), 16r (Wulfsige), 39v (Æthelwold).

${ }^{88}$ They appear in the calendars from before 1100 catalogued by Rushforth in Saints in English Kalendars, and in Anglo-Saxon Litanies of the Saints, ed. Lapidge, as well as the martyrologies analysed in Tables 1 and 2 as follows: Edward (March $18^{\text {th }}$ ) - seventeen calendars before 1100, fifteen Anglo-Saxon litanies and five martyrologies; Edith/Eadgyth (September $16^{\text {th }}$ )- three calendars, seven litanies, four martyrologies; translation of Swithun $\left(\right.$ July $\left.15^{\text {th }}\right)$ - eighteen calendars, fourteen litanies, three martyrologies; Kenelm $\left(\right.$ July $\left.17^{\text {th }}\right)-$ eighteen calendars, fourteen litanies, three martyrologies; Neot (July $\left.31^{\text {st }}\right)$ - three calendars, four litanies, two martyrologies. 
${ }^{89}$ The entries for Oswald and Edward the Martyr were added slightly later in the margin on fols. 35r, 40r; an extensive entry for Chad was added at the end of that for $2^{\text {nd }}$ March in a slightly later s. xii hand, fol. 35v.

${ }^{90}$ E.g. 'In Britannia sancti Albani martyris...': Le Martyrologe d'Usuard, ed. Dubois, 252.

${ }^{91}$ I would like to thank the anonymous reviewer who suggested this interpretation.

${ }^{92}$ Fol. $28^{\text {r: }}$ "In brittannia maiori prouincia cantia loco qui dicitur limbiacum sanctae eadburgae uirginis", fol. $36^{\mathrm{r}}$ : "Item translatio sanctae eadburgae uirginis". Cf. the entries in the twelfth-century martyrology from the secular community of St Chad's, Shrewsbury, now Oxford, Bodleian Library, Ms Rawlinson D 1225, fols. 70r, 80r: (15" June) "XVII Kalends Iulii.... Eodem die sanctae eadburge uirginis in uuentana ciuitate sanctae marie monasterio quiescentis cuius uitae sanctitas multiplex post mortem fulsit sanctitate." ; (18 ${ }^{\text {th }} \mathrm{July}$ ) "XV Kalends Aug....Ipso die translatio sanctae eadburgae uirginis," There is no entry for the cult of any Eadburh on these dates, by contrast, in London, British Library, Ms Royal 7 E.vi. ${ }^{93}$ Ordinale Exon., IV. 56, n. 1. John Blair records five different saints by that name: John Blair, "A Handlist of Anglo-Saxon Saints," in Local Saints, eds Thacker and Sharpe, 495565 , at 525-27.

${ }^{94}$ Rushforth, Saints in English Kalendars, Table VI (14/27 calendars). This is the feast recorded in the twelfth-century martyrology from St Chad's, Shrewsbury, for example for which see $n .87$ above.

95 Blair, "Handlist", 526.

${ }^{96}$ Fol. $35^{\text {r. }}$ "In britannia maiori loco qui dicitur weneloc sanctae mildridae uirginis" (13 July). See also the account by Blair, "Handlist", 545.

${ }^{97}$ Simon Yarrow, "The Invention of St Mildburg of Wenlock: Community and Cult in an Anglo-Norman Shropshire Town,” Midland History 38 (2013): 1-15. 
${ }^{98}$ Saints, ed. Rushforth, Table VII. On her cult see David W. Rollason, The Mildrith Legend. A Study in Early Medieval Hagiography (Leicester, 1982). E.g. The Christ Church martyrology includes the following entry for $13^{\text {th }}$ July: London, British Library, Ms Royal 7 E.vi, fol. 39v: "Cantuariae sanctae MILDRITHE uirginis.”; there is no entry in either June or February for Mildburga.

${ }^{99}$ Fol. $4^{\mathrm{r}}$ : “Item sanctae mildburgae uirginis" (23 February); Rushforth, Saints in English Kalendars, Table II; Blair, "Handlist”, 544-45.

${ }^{100}$ Richard Sharpe, “Goscelin’s St Augustine and St Mildreth: Hagiography and Liturgy in Context,” Journal of Theological Studies, NS, 41 (1990): 502-16; Richard Sharpe, “The Date of St Mildrith's Translation from Minster-in-Thanet to Canterbury," Mediaeval Studies 53 (1991): 349-54; Rollason, The Mildrith Legend.

${ }^{101}$ Fol. 19" : "Item ipso die translatio beatissimi archepiscopi nicholai quando sacratissimum eius corpus de mirrea ciuitate in uarensem urbem translatum est."

${ }^{102}$ Marjorie Chibnall, “The Translation of the Relics of Saint Nicholas and the Norman Historical Tradition," in her Piety, Power and History in Medieval England and Normandy (Aldershot, 2000), no. III. See also Karl Meisen, Nikolauskult und Nikolausbrauch im Abendlande: eine Kultgeographische-Volkskundliche Untersuchung (Düsseldorf, 1931); Patrick Geary, Furta Sacra. Theft of Relics in the Central Middle Ages (Princeton, NJ, 1978), 94-103.

${ }^{103}$ See n. 80 above.

${ }^{104}$ Marginal addition in s. xii hand in both Durham, Cathedral Library, Ms B. IV. 24, fol. 22r, "Eodem die translatio sancti Nicholaii," and Oxford, Bodleian Library, Ms Rawlinson D. 1225, fol. 56v: "Eodem die translatio sancti nicholaii episcopi preciosi confessoris ad 
barum." No reference to Nicholas of Bari (nor room for it to have been erased) from entry for May $8^{\text {th }}, 9^{\text {th }}$ or $10^{\text {th }}$ : London, British Library, Ms Royal 7 E.vi, fols. 26r-v.

${ }^{105}$ Exeter 3518, fol. 45r: "Ciuitate rotamago sancti audoeni confessoris qui saeculum salubriter despiciens sanctitatis merito episcopii adeptus est honorem." Cf. Le Martyrologe d'Usuard, ed. Dubois, 289. Audoenus's cult is recorded in some nine English calendars from before 1100, mostly from houses linked to the reform centre of Winchester: Saints in English Kalendars, ed. Rushforth, Table VIII.

106 “Ciuitate rotamagensi ordinatio sancti audoeni episcopi et confessoris”, fol. 20v.

${ }^{107}$ Rouen, Bibliothèque municipale, MS Y.21 (s. xi ${ }^{\mathrm{ex}}$, St Ouen); Paris, Bibliothèque nationale de France, Ms lat. 15697 (s. xii, prob. St Ouen). I owe these references to Dr Christopher Hodkinson (personal communication, $13^{\text {th }}$ May 2017), whom I should like to thank for his detailed advice on the medieval liturgical evidence for the cult of St Audoenus in the diocese of Rouen. This feast was not observed in any of the surviving manuscripts for the secular use of Rouen.

${ }^{108}$ See n. 81 above.

${ }^{109}$ Eadmer (d. c. 1126) reports that Audoenus's relics were translated from Rouen to Christ Church, Canterbury 957x958, and that the mid-tenth-century scholarFrithegod wrote a now lost Life of St Ouen; he goes on to record that Osbern, praecentor of Canterbury (d. 1093) rediscovered a complete skeleton in a reliquary in the 1090s helpfully labelled "The relics of holy confessor Audoenus": Eadmer, De Reliquiis Sancti Audeoni et Quorundam Aliorum Sanctorum quae in Cantuariae in Aecclesia Domini Salvatoris Habentur, ed. Andre Wilmart, Revue des sciences religieuses 15 (1935): 364-5. That this tradition has some grounding in reality: Michael Lapidge, “A Frankish Scholar in Tenth-century England: Frithegod of Canterbury/Fridegaude of Brioude," in his Anglo-Latin Literature, 2 vols (London, 1993), 
2:157-181. William of Malmesbury, however, reported that Queen Emma purchased the relics from the church of St-Ouen during her exile in Normandy in the early eleventh century, and brought them to Canterbury upon her return, but kept the skull which was in Malmesbury by his time: Gesta Pontificum Anglorum, I: 626-28. The feast is not recorded on this date in the Christ Church martyrology, London, British Library, Ms Royal 7 E.vi.

${ }^{110}$ For the suggestion that Warelwast took his name from Ver-à-Val in the demesne of the Rouen abbey of St Wandrille see Frank Barlow, "William de Warelwast," Oxford Dictionary of National Biography.

${ }^{111}$ Fols. $25^{\mathrm{r}}, 27^{\mathrm{v}}, 57^{\mathrm{v}}$. See n. 38 above for Leofric's upbringing.

${ }^{112}$ Fols. $8^{\mathrm{r}}$ ("Ciuitate colonia depositio sancti hereberti episcopi et confessoris"), $32^{\mathrm{v}}$ ("Eodem die ciuitate augusta sancti odolrici episcopi et confessoris"), 54r ("Item eodem die sancti wenezlai"), $35^{\vee}$ (“Item romae sancti alexi confessoris"). Heribert's cult was largely confined to the diocese of Cologne and did not spread across the province nor more widely across the empire in this period: H. Müller, Heribert, Kanzler Ottos III. und Erzbischof von Köln (Cologne, 1977), 306-32. Otto III donated his coronation robe to St Alexius in Rome: Louk J. Engels, “The West European Alexius Legend with an Appendix Presenting the Medieval Latin Text Corpus in its Context," in The Invention of Saintliness, ed. Anneke B. Mulder-Bakker (London, 2002), 93-144.

${ }^{113}$ Chronicon Abbatiae de Evesham, ed. William D. Macray, Rolls Series 29 (London, 1863), 83, 313-20; Blair, "Handlist," 548.

${ }^{114}$ Durham, Ms B.IV.4, fol. 18v: "Coloniae sancti heriberti archiepiscopi eiusdem ciuitatis cuius uitam inclitam miracula post obitum eius facta testantur." Cf. text in Exeter 3518 at n. 108 above. 
${ }^{115}$ Eucharius is mentioned in a calendar compiled at eighth-century Echternach in the diocese of Trier by a scribe associated with the Anglo-Saxon mission. Whilst it includes various early Anglo-Saxon cults, this entry is likely to be a continental addition: Saints, ed. Rushforth, Table XII.

${ }^{116}$ Anglo-Saxon Litanies, ed. Lapidge, no. XXIII, 193-202, lines 226 (Symeon), 238 (Odwulf), 193 (Udalrich), 200 (Eucharius). Heribert also features in a litany in a copy of the Romano-German pontifical made in England, possibly from a Cologne exemplum, now Cambridge, Corpus Christi College, Ms 163: ibid., 107, no. IV.i.58. Symeon (possibly of Trier) also features in two other litanies edited by Lapidge: the first is a litany containing only one Anglo-Saxon saint amongst a list of Frankish names in an English sacramentary taken to Fleury: Orléans, Bibliothèque municipal 127, ibid., 221, no. XXVIII.112; the second in what is probably the longest litany surviving from Anglo-Saxon England in a prayer collectionwritten in the late tenth or early eleventh century, now London, British Library, Ms Cotton Galba A.xiv, ibid., 168, no. XVI.ii.276. The provenance of Ms Cotton Galba A.xiv is much debated. For the most recent account, and a survey of earlier scholarship, see Julia Crick, "An Eleventh-century Prayer-Book for Women? The Origins and History of the Galba Prayer-Book," in Writing, Kingship and Power in Anglo-Saxon England, eds Rory Naismith and David A. Woodman (Cambridge, 2018), 281-302; her palaeographical analysis suggests a western English provenance and raises doubts about the palaeographical credibility of Joe Hillaby's suggestion of a Leominster provenance made across various publications: "Early Christian and Pre-Conquest Leominster: An Exploration of the Sources," Transactions of the Woolhope Naturalists' Field Club 45 (1987), 557-685; “Leominster and Hereford: The Origins of the Diocese," in Medieval Art, Architecture and Archaeology at Hereford, British Archaeological Association Conference Transactions 15, ed. David Whitehead (Leeds, 1995), 
1-14 at 6-8; "The Early Church in Herefordshire: Columban and Roman," in The Early Church in Herefordshire: Proceedings of a Conference Held in Leominster in June 2000, ed. Ann Malpas (Leominster, 2001), 41-76 at 45-47, 59-60. Eucharius features also in a fifteenthcentury litany added to an eleventh-century psalter (Anglo-Saxon Litanies, ed. Lapidge ., 215, no. XXVII.76 (Eutharius)), and in a litany in a psalter written in Brittany in the early tenth century and brought to England in the Anglo-Saxon period, now Salisbury, Cathedral Library, Ms 180 (ibid., 291, no. XLIV.141).

${ }^{117}$ Anglo-Saxon Litanies, ed. Lapidge, 74.

${ }^{118}$ Fol. 13 $3^{\mathrm{v}}$ : "Item romae sancti leonis papae et confessoris".

${ }^{119}$ Franz Neiske, "La memoria de Léon IX dans les nécrologes et les martyrologes," in Léon IX et son temps, eds Georges Bischoff and Benoît-Michel Tock (Turnhout, 2006), 633-45.

${ }^{120}$ His entry is added interlinearly in a hand from s. $\mathrm{xi}^{2}$ : Anglo-Saxon Litanies, ed. Lapidge, 199, no. XXIII.267.

${ }^{121}$ Leofric Missal, ed. Orchard, 2: 4-5.

${ }^{122}$ Bede may be the source of many but not all of Durham's local entries: Benedict Biscop (12 $2^{\text {th }}$ January), Cuthbert (20 ${ }^{\text {th }}$ February), John of Beverley ( $7^{\text {th }}$ May), Bede (26 $6^{\text {th }}$ May), Oswald king and martyr (August $5^{\text {th }}$ ), Aidan of Lindsifarne (August $31^{\text {st }}$ ), translation of Cuthbert (September $\left.4^{\text {th }}\right)$, Wilfrid $\left(12^{\text {th }}\right.$ October $)$, Hilda $\left(20^{\text {th }}\right.$ November $)$; the other additions relate to Anglo-Saxon cults outside the north east: Piper, "The Durham Cantor's Book," 9092.

${ }^{123}$ Fol. $22^{\mathrm{v}}$ : "In brittannia maiori ciuitate exonia translatio sanctarum reliquiarum quarum translatio magnis et multis commendatur miraculis." Nothing is known of these miracles; so far as I am aware, the only report of miracles in Exeter in the twelfth and thirteenth centuries 
is that of Hermann of Tournai, writing in the 1140s about a fund-raising relic tour of southern England undertaken by the canons of Laon in 1113, who reports that Laon's relics of the Virgin Mary cured 17 sick people in Exeter: De Miraculis S. Mariae Laudunensis, ed. J.-P. Migne, Patrologia Latina 156 (Paris, 1853), 961-1018 at 982. On this account see Simon Yarrow, Saints and Their Communities: Miracle Stories in Twelfth-Century England (Oxford, 2006), ch. 3; also Pierre-André Sigal, "Les Voyages de reliques aux onzième et douzième siècles," in Voyage, quête, pélerinage dans la littérature et la civilisation médiévales (Aix-en-Provence, 1976), 73-104; Reinhold Kaiser, "Quêtes itinérantes avec des reliques pour financer la construction des églises (XIe-XIIe siècles)," Le moyen âge, 101 (1995): 205-25.

${ }^{124}$ Anglo-Saxon Exeter, ed. Conner, 171-209. For the role of Æthelstan in the historical memory of the Exeter community in the 1050s see Charles Insley, "Remembering Communities Past: Exeter Cathedral in the Eleventh Century," in Cathedrals, Communities and Conflict in the Anglo-Norman World, ed. Paul Dalton, Charles Insley and Louise J. Wilkinson (Woodbridge, 2011), 41-60. On the role of the relic collection see Julia M. H. Smith, "Rulers and Relics c. 750-c.950: Treasure on Earth, Treasure in Heaven," in Relics and Remains, ed. Alexandra Walsham, Past and Present Supplements new series 5 (Oxford, 2010), 73-96.

${ }^{125}$ Annals of Tavistock, a. 1114, 1133 cited by Frances Rose-Troup, Exeter Vignettes (Manchester, 1942), 24.

${ }^{126}$ Fol. 39v:'In brittannia foras murum ciuitatis exoniae sanctae satiuolae uirginis et martyris."

${ }^{127}$ Old English Relic List (Oxford, Bodleian Library, Ms Auct. D. 2.16, fols. 8r-14r), AngloSaxon Exeter, ed. Conner,187. 
${ }^{128}$ M. Förster, "Die heilige Sativola oder Sidwell," Anglia 62 (1938): 33-80; Paul Grosjean, “Legenda S. Sativolae Exoniensis,” Analecta Bollandiana 53 (1935): 359-65.

${ }^{129}$ Fol. $35^{\text {r. }}$ "In britannia quod apud sireburniam translatio sanctae iuthuarae uirginis sororis sanctae satiuolae uirginis.”

${ }^{130}$ Blair, "Handlist," 542-3. Rosalind Love, "The Life of St Wulfsige of Sherborne by Goscelin of Saint-Bertin: A New Translation with Introduction, Appendix and Notes," in St Wulfsige and Sherborne: Essays to Celebrate the Millennium of the Benedictine Abbey 9981998, eds Katherine Barker, David A. Hinton and Alan Hunt (Oxford, 2005), 98-117 at 101$2,115-17$

${ }^{131}$ The evidence of Exeter 3518 for Cornish cults has received more attention from scholars than that for Devonian cults; for a summary of this work see the relevant entries in Orme, Saints in Cornwall.

${ }^{132}$ Fols. 46v-47r: "In brittannia maiori loco qui dicitur tauistoca depositio sancti rumoni confessoris".

${ }^{133}$ Christopher Holdsworth, "Tavistock Abbey in Its Late Tenth-century Context," The Devonshire Association for the Advancement of Science, Literature and Art. Report and Transactions 135 (2003): 31-58. For the argument that the foundation charter, which is dated to 981 and presumes a pre-existing community, was actually written after 997, see Levi Roach, "The Privilege of Liberty in Anglo-Saxon England," in Magna Carta, eds Nick Vincent and Sophie Amblers (forthcoming).

${ }^{134}$ Rollason, "List of Saints' Resting Places”, 92 (no. 39). On the cult see G. H. Doble, ‘Saint Rumon', Cornish Saints Series, no. 42 (Long Compton, 1939), repr. in idem, The Saints of Cornwall, 5 vols (Oxford, 1960-70), 2: 120-34; Paul Grosjean, "Vie de S. Rumon. 
Vie, invention et miracles de S. Nectan," Analecta Bollandiana 71 (1953): 359-414 at 361-75 and 393-97.

${ }^{135}$ Frank Barlow, "Lyfing (d. 1046)," Oxford Dictionary of National Biography On-line (accessed $14^{\text {th }}$ June 2017). Some ten manumissions for servi living on Tavistock's estates are recorded on a singleton sheet added to the Leofric Missal sometime in the second quarter of the eleventh century which suggests that by the 1040s that codex was owned by the community at Crediton (where the see was located prior to its move to Exeter in 1050) and that the bishopric had close ties to Tavistock: The Leofric Missal, ed. Orchard, 2: 14-15.

${ }^{136}$ It is also feasible, if less likely, that Rumon came to Exeter via a text from Glastonbury, as David Rollason has suggested his cult may have been known there in the early Middle Ages because Glastonbury possessed an arm relic of Rumon in the fourteenth century. Rollason thus suggests Glastonbury took on the Cornish cults of SS Rumon and Kea as part of its attempts to consolidate its political authority in the south west, as this fits with a wider pattern of political exploitation of relic cults: Saints and Relics, 154; also his "Relic-cults as an Instrument of Royal Piety,” Anglo-Saxon England 15 (1986): 91-103 at 101-2.

${ }^{137}$ Fol. 28v: "In brittannia maiori prouincia deuonia sancti nectani martyris".

${ }^{138}$ Grosjean, "Vie,” 377.

${ }^{139}$ Grosjean, "Vie”, 402-5 (Æthelstan), 408-8 (Gytha). Susan Pearce, "The Early Church in the Landscape: The Evidence from North Devon," Archaeological Journal 142 (1981): 23375.

${ }^{140}$ Grosjean, "Vie," 402-5.

${ }^{141}$ Fols. $1^{\mathrm{r}}, 2^{\mathrm{v}}$, and $23^{\mathrm{r}}$.

${ }^{142}$ Lepine and Orme, Death and Memory, 232. 
${ }^{143}$ Leofric Missal, ed. Orchard, 2: 59. Similarly Bishop Eadwulf, the first bishop of Crediton (c. 909-?934) is recorded in the Missal but not the martyrology: ibid., 2: 67; see Prosopography of Anglo-Saxon England, http://pase.ac.uk (accessed $22^{\text {nd }}$ June 2017). ${ }^{144}$ Rose-Troup, Exeter Vignettes, 23-4.

145 Blake, "Bishop William Warelwast".

${ }^{146}$ Fols. 17r, 6v.

${ }^{147}$ Edmund King, King Stephen (New Haven, Connecticut, 2010). Exeter was part of the dower of Mathilda, wife of Henry I, which might also explain her inclusion; I owe this suggestion to Professor Judith Green.

${ }^{148}$ F, 53": "MLXVI Haraldus filius Godwini comitis rex anglorum occiso Haraldo rege normannorum omnique suo exerciti uictorissime triumphauit in quo etiam bello comes Tostis frater praedicti regis anglorum cum rege normannorum ab anglis occisus est”".

${ }^{149}$ To my knowledge. I should like to thank the anonymous reviewer of this article suggesting that the source may not have been in Latin but rather the vernacular, and drawing my attention to the parallels with the C-text of the Anglo-Saxon Chronicle, s.a. 1066, in which mentions the deaths of Harold of Norway and Tostig in the same order: The AngloSaxon Chronicle: A Collaborative Edition, general eds David Dumville and Simon Keynes, Volume 5: MS C: A Semi-Diplomatic Edition with Introduction and Indices, ed. Katherine O’Brien O'Keefe (Cambridge, 2001), 122. To my mind, the parallels are not sufficiently close to suggest a close relationship. By publishing the text here I hope that others may be able to identify its source.

${ }^{150}$ The Durham Liber Vitae. MS Cotton Domitian A.VII: Edition and Digital Facsimile with Introduction, Codicological, Prosopographical and Linguistic Commentary, and Indices, ed. 
David and Lynda Rollason, 3 vols, (London: British Library, 2007), 1: 92. On Tostig's life and reputation see William M. Aird, "Tostig, Earl of Northumbria”, Oxford Dictionary of National Biography (Oxford, 2004-2016), at www.oxforddnb.com (last accessed $29^{\text {th }}$ November 2018).

${ }^{151}$ The acknowledgement of Harold as king in a mid-twelfth-century text without any obvious polemical purpose may be of interest to scholars interested in the ways in which twelfth-century Norman rulers set out to claim political legitimacy e.g. George Garnett, Conquered England. Kingship, Succession and Tenure, 1066-1166 (Oxford, 2007). For reservations about Garnett's argument see Nick Vincent's review in History 95 (2010): 1068.

${ }^{152}$ London, British Library, Ms Cotton Vitellius C. xii, fol. 145v. For an image of this entry, and brief description of this manuscript, see Anglo-Saxon Kingdoms: Art, Word, War, eds Claire Breay and Joanna Story (London, 2018), 388-89 (no. 158). On evidence for AngloSaxon scribes at work on this manuscript, as evidenced by continuity of Anglo-Saxon drawing styles, see Richard Gameson, "English Manuscript Art in Late Eleventh-century Canterbury and Its Context," in Canterbury and the Norman Conquest: Churches, Saints and Scholars, 1066-1109, eds Richard Eales and Richard Sharpe (London, 1995), 95-144 at 1012, 126, n. 114.

${ }^{153}$ The Chronicle of John of Worcester, ed. R. R. Darlington and P. McGurk, trans. Jennifer Bray and P. McGurk, 3 vols (Oxford, 1995-1998), 3: 4-7; Tara Gale, John Langdon and Natalie Leishman, "Piety and Political Accommodation in Norman England: the Case of the South West," The Haskins Society Journal 18 (2006): 110-31 at 112-4; Robert Higham, "William the Conqueror's Siege of Exeter in 1068," The Devonshire Association for the 
Advancement of Science, Literature and the Arts: Report and Transactions 145 (2013): 93132 at $101-2$.

${ }^{154}$ The sacramentary-pontifical known as the Leofric Missal came to eleventh-century Crediton from Canterbury: Leofric Missal, ed. Orchard, 1:206-8. That the mid-twelfthcentury pontifical, now London, British Library, Ms Cotton Vespasian D.xv made a similar journey is clear from the rite for ordaining an abbot, where the abbot's promise of obedience made to the see of Canterbury, Dorobernensi, has been erased and emended to read Exoniensi (fol. 22r), on which see Sarah Hamilton, “Absoluimus uos uice beati petri apostolorum principis: Episcopal Authority and the Reconciliation of Excommunicants in England and Francia, c. 900-c.1150," in Frankland. The Franks and the World of the Early Middle Ages. Essays in Honour of Dame Jinty Nelson, eds Paul Fouracre and David Ganz (Manchester, 2008), 209-41 at 210-11; Helen Gittos suggested that the benedictional text of the late eleventh-century Exeter pontifical-benedictional, now London, British Library, MS Additional 28188 might also have immediate roots in Canterbury, based on a suggestion by C.A.Jones (personal communication), rather than the more usually accepted arguments for Winchester influence e.g. those of Andrew Prescott, "The Structure of English Pre-Conquest Benedictionals," British Library Journal 13 (1987): 118-58. Richard Gameson has identified various other manuscripts which were acquired by Exeter from both St Augustine's and Christ Church, Canterbury in the late eleventh and early twelfth centuries including Amalarius (St Augustine's), Boethius (St Augustine's/Christ Church), Persius (St Augustine's/Christ Church), Gregory the Great's Regula Pastoralis (St Augustine's/Christ Church): "The Origins of the Exeter Book," 148-51.

${ }^{155}$ Helen Gittos, Liturgy, Architecture, and Sacred Places in Anglo-Saxon England (Oxford, 2013), 123, 128-9, 229-30. 
${ }^{156}$ Christopher A. Jones, "Performing Christianity: Liturgical and Devotional Works," in Clare A. Lees, ed., The Cambridge History of Early Medieval English Literature (Cambridge, 2013), 427-50 at 430-31.

${ }^{157}$ Gameson, "The Origins of the Exeter Book”, 184.

${ }^{158}$ See other references in n. 30 above.

${ }^{159}$ David W. Rollason, “Relic-Cults as Instrument of Royal Policy, 900-1050”, Anglo-Saxon England 15 (1986): 91-103; Anne Wagner, “Collection de reliques et pouvoir épiscopal au Xe siècle. L'exemple de l'évêque Thierry Ier de Metz," Revue d'histoire de l'Église de France 83 (1997): 317-41; Brigitte Meijns, "Les premières collégiales des comtes de Flandre, leur reliques et les conséquences des invasions normandes (IXe-Xe siècles)," Revue belge de philologie et d'histoire 85 (2007): 539-75.

${ }^{160}$ Rubenstein, "Liturgy Against History”.

${ }^{161}$ Lapidge's Cult of St Swithun succeeds in presenting the wide range of different evidence for this cult but is still dominated by narrative and poetic texts.

${ }^{162}$ On the general significance of martyrological and obituary evidence see Margot Fassler, "The Liturgical Framework of Time and the Representation of History," in Representing History, 900-1300: Art, Music, History, ed. Robert Maxwell (Philadelphia, 2010), 149-72; eadem, The Virgin of Chartres: Making History Through Liturgy and the Arts (New Haven and London, 2010), 23-4: "alongside the legends another kind of historical understanding brewed within the liturgy itself, an elemental historical process that conditioned the minds not only of medieval cantors but of all learned medieval Christians. In case after case - eleventhcentury Chartres is but one example - cantors and the scribes who were normally under their auspices had charge of two essential kinds of materials: those that belonged to the liturgy including obituaries and martyrologies, and the chronicles and other written histories." 
${ }^{163}$ For a parallel exercise demonstrating the ways in which the Anglo-Norman community of Christ Church, Canterbury drew upon and revised the rites for church dedication and the chrism mass see Helen Gittos, "Sources for the Liturgy of Canterbury Cathedral in the Central Middle Ages," in Medieval Art, Architecture and Archaeology at Canterbury, ed. Alixe Bovey, Transactions of the British Archaeological Association 35 (2013), 41-58, at 46: “The liturgists who put together Anselm's and Lanfranc's own pontificals based them on late Anglo-Saxon manuscripts"; Christopher A. Jones, "The Origins of the "Sarum" Chrism Mass at Eleventh-century Canterbury," Mediaeval Studies 67 (2005): 219-35. 